Prepared in cooperation with Northern Arizona University

Gully Monitoring at Two Locations in Grand Canyon National Park, Arizona, 1996-2010, with Emphasis on Documenting Effects of the March 2008 High-Flow Experiment

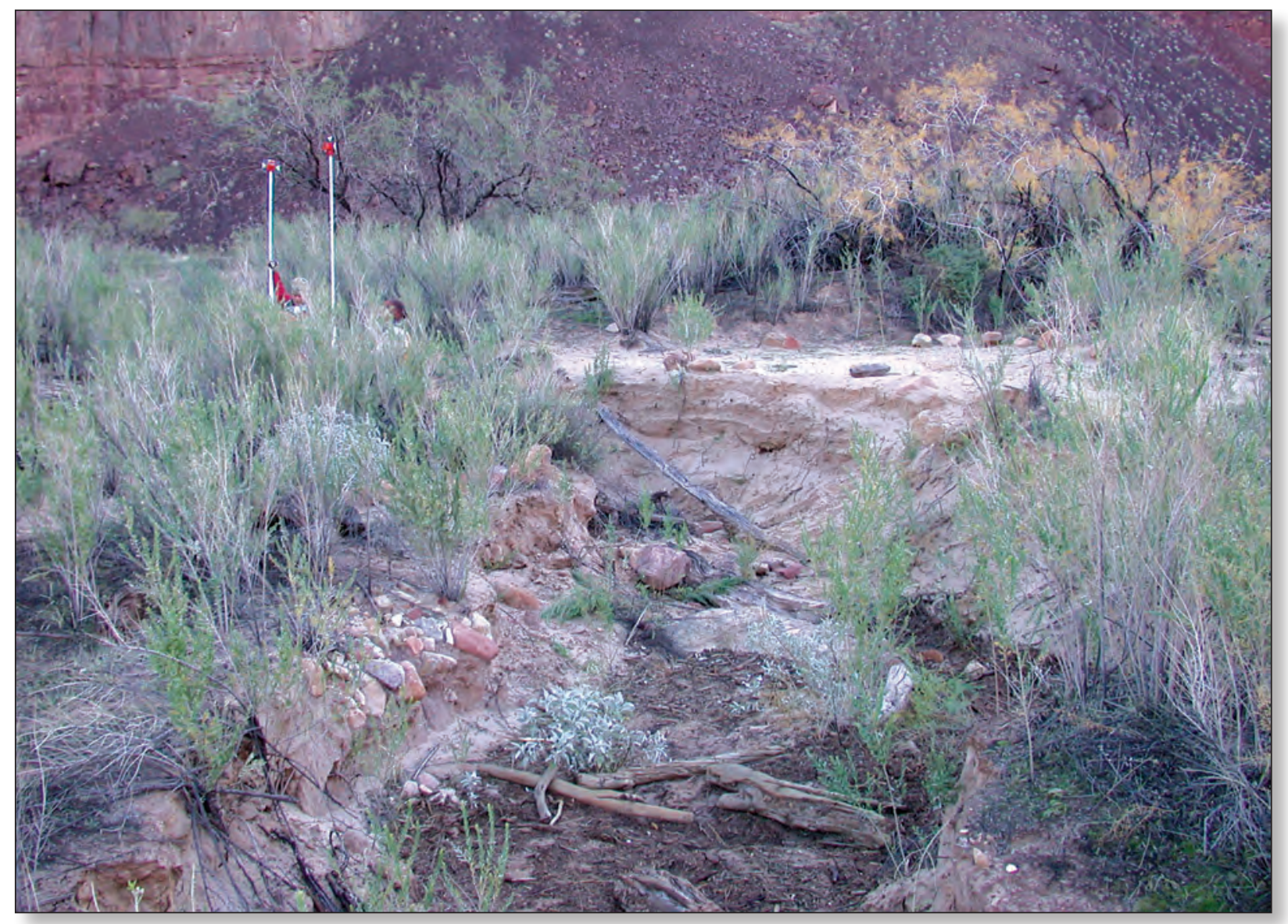

Open-File Report 2014-1211 
Cover: Surveyors mapping the Palisades gully network after the 2008 high-flow experiment on the Colorado River, Grand Canyon National Park, Arizona. Photograph by A. East, U.S. Geological Survey, December 10, 2004. 


\section{Gully Monitoring at Two Locations in the Grand Canyon National Park, Arizona, 1996-2010, with Emphasis on Documenting Effects of the March 2008 High-Flow Experiment}

By Nathan D. Schott, Joseph E. Hazel, Jr., Helen C. Fairley, Matt Kaplinski, and Roderic A. Parnell

Prepared in cooperation with Northern Arizona University

Open-File Report 2014-1211

U.S. Department of the Interior

U.S. Geological Survey 


\section{U.S. Department of the Interior \\ SALLY JEWELL, Secretary}

\section{U.S. Geological Survey \\ Suzette Kimball, Acting Director}

U.S. Geological Survey, Reston, Virginia: 2014

For more information on the USGS-the Federal source for science about the Earth,

its natural and living resources, natural hazards, and the environment-visit

http://www.usgs.gov or call 1-888-ASK-USGS

For an overview of USGS information products, including maps, imagery, and publications, visit $h$ ttp://www.usgs.gov/pubprod

To order this and other USGS information products, visit $h$ ttp://store.usgs.gov

Suggested citation:

Schott, N.D., Hazel, J.E., Jr., Fairley, H.C., Kaplinski, M., and Parnell, R.A., 2014, Gully monitoring at two locations in the Grand Canyon National Park, Arizona, 1996-2010, with emphasis on documenting effects of the March 2008 highflow experiment: U.S. Geological Survey Open-File Report 2014-1211, 32 p., http://dx.doi.org/10.3133/ofr20141211.

ISSN 2331-1258 (online)

Any use of trade, product, or firm names is for descriptive purposes only and does not imply endorsement by the U.S. Government.

Although this report is in the public domain, permission must be secured from the individual copyright owners to reproduce any copyrighted material contained within this report. 


\section{Contents}

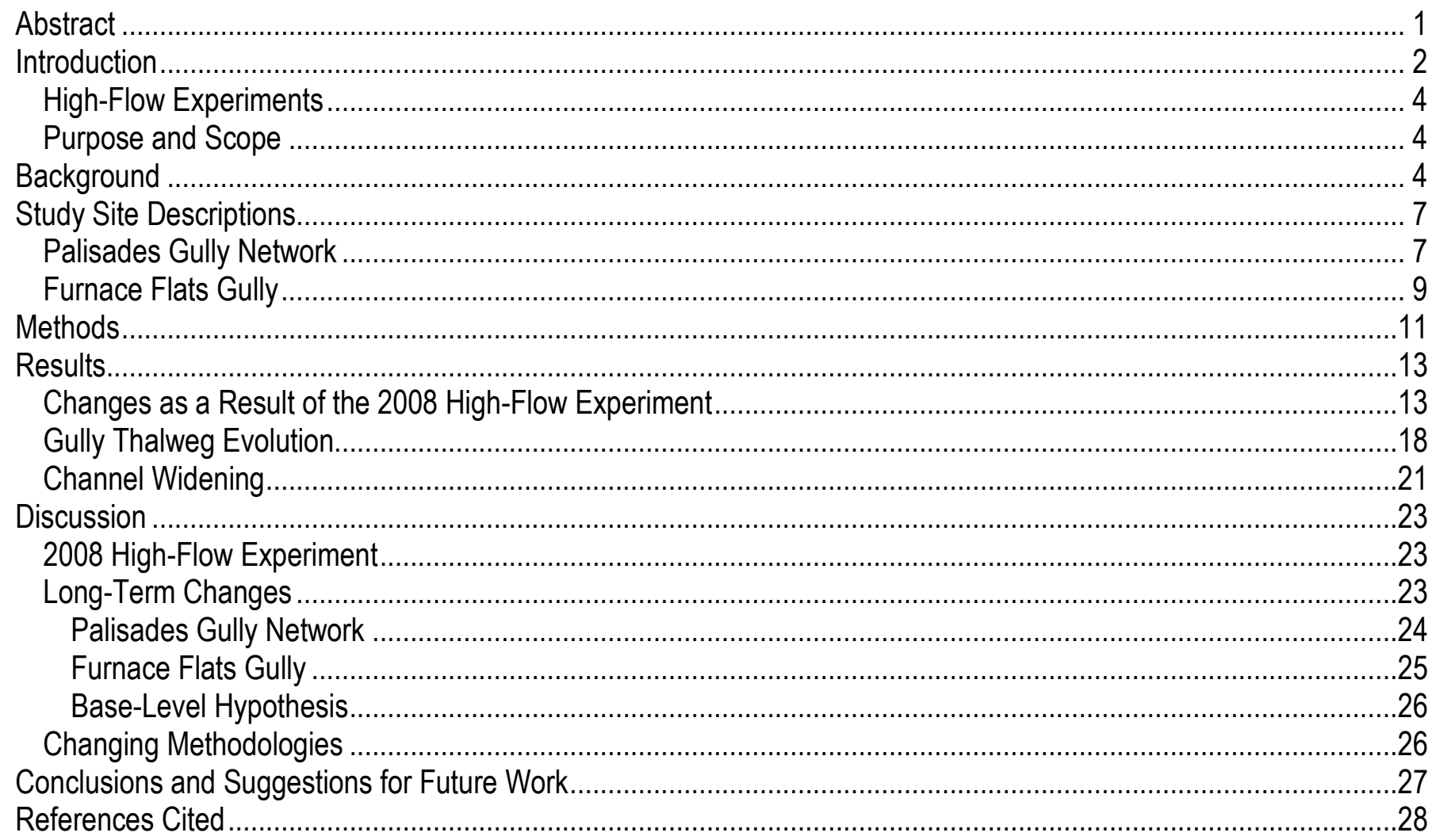

\section{Figures}

Figure 1. Map showing (A) general location of study area within the Grand Canyon National Park, Arizona and (B) the two specific study areas in the eastern Grand Canyon National Park, Arizona.

Figure 2. Photograph showing mouth of the Palisades South gully, Grand Canyon National Park, Arizona, February 9, 2008

Figure 3. Aerial photograph showing Palisades study area, Grand Canyon National Park, Arizona, May 2002 _......... 8

Figure 4. Photographs showing examples of erosion control structures constructed to reduce gully erosion at the Palisades South gully

Figure 5. Aerial photograph showing Furnace Flats gully, Grand Canyon National Park, May 2002

Figure 6. Selected repeat photographs showing the Palisades South gully as viewed looking northeast from the terminus near the Colorado River

Figure 7. Repeat photographs showing Palisades South gully upper mouth area from (A) April 19, 2007, 11 months prior to the 2008 high-flow experiment and $(B)$ April 4, 2008, just after the 2008 high- flow experiment.... 15

Figure 8. Cross sections across the mouth of the Palisades South gully, Grand Canyon National Park, Arizona ..... 16

Figure 9. Normalized profile of the Palisades North gully, Grand Canyon National Park, Arizona, 1998-2010 ….... 17

Figure 10. Cross sections at the Furnace Flats gully, Grand Canyon National Park, Arizona.................................. 19

Figure 11. Normalized long profile of the Palisades South gully, Grand Canyon National Park, Arizona, 2004-2010 
Figure 12. Normalized short profile of the Palisades South gully, Grand Canyon National Park, Arizona, 1998-2010

Figure 13. Normalized profile of the Furnace Flats gully, Grand Canyon National Park, Arizona, 1996-2008 .......... 21

Figure 14. Cross sections at the Palisades gully network established by the National Park Service, Grand Canyon National Park, Arizona, January 1998

\section{Tables}

Table 1. Topographic surveys conducted at the Palisades South gully network, Grand Canyon

National Park, Arizona

Table 2. Volume of scour and fill in the mouth of the Palisades South gully for the three high-flow experiments (HFE) and the intervals in between

\section{Conversion Factors and Datums}

\section{Conversion Factors}

SI to Inch/Pound

\begin{tabular}{lll}
\hline \multicolumn{1}{c}{ Multiply } & \multicolumn{1}{c}{ By } & \multicolumn{1}{c}{ To obtain } \\
\hline centimeter $(\mathrm{cm})$ & Length & \\
millimeter $(\mathrm{mm})$ & 0.3937 & inch (in.) \\
meter $(\mathrm{m})$ & 0.03937 & inch (in.) \\
kilometer $(\mathrm{km})$ & 3.281 & foot (ft) \\
kilometer $(\mathrm{km})$ & 0.6214 & mile (mi) \\
meter $(\mathrm{m})$ & 0.5400 & mile, nautical (nmi) \\
\hline & 1.094 & yard (yd) \\
\hline cubic meter $\left(\mathrm{m}^{3}\right)$ & Volume & \\
\hline
\end{tabular}

\section{Datums}

Vertical and horizontal coordinate information is referenced to the 2007 realization of the National Spatial Reference System, North American Datum of 1983, NAD83 (NSRS2007), in meters.

Elevation, as used in this report, refers to GPS derived ellipsoid height above the GRS80 ellipse, in meters, and not NAVD88 orthometric height. 


\title{
Gully Monitoring at Two Locations in the Grand Canyon National Park, Arizona, 1996-2010, with Emphasis on Documenting Effects of the March 2008 High-Flow Experiment
}

\author{
By Nathan D. Schott ${ }^{1}$, Joseph E. Hazel, Jr. ${ }^{1}$, Helen C. Fairley², Matt Kaplinski ${ }^{1}$, and Roderic A. Parnell1
}

\begin{abstract}
Many archeological sites in the Grand Canyon are being impacted by gully incision. In March 2008, a high-flow experiment (2008 HFE) was conducted with the intention of redistributing fine sediment (sand, silt, and clay) from the bed of the Colorado River to higher elevations along the channel margin. Deposition of fine sediment in gully mouths has been hypothesized to slow gully erosion rates and lessen impacts to archeological sites. The effects of the 2008 HFE on gullies were evaluated by comparing the topographic changes of three gullies at two study sites before and after the 2008 HFE. Comparison results indicated that sediment was deposited in gully mouths during the $2008 \mathrm{HFE}$, and that the inundated areas nearest to the river can be extensively altered by mainstream flow during high-flow events. Additionally, the history of gully evolution at the two study sites was examined between 1996 and 2010 and indicated that gullies have been subjected to thalweg incision and gully widening processes over a decadal timescale. Although the small sample size precludes extrapolating the results to other gullies, the findings contribute to the understanding of gully erosion in archeologically significant areas and have implications for future monitoring of gully erosion and evaluating the effectiveness of check dams intended to mitigate that erosion at archaeological sites in the Grand Canyon National Park.
\end{abstract}

\footnotetext{
${ }^{1}$ Northern Arizona University.

${ }^{2}$ U.S. Geological Survey.
} 


\section{Introduction}

Completion of Glen Canyon Dam in 1963 altered the downstream hydrology of the Colorado River by significantly reducing the supply of fine sediment (sand, silt, and clay), eliminating the annual spring snowmelt flood, replacing seasonal flow fluctuations with a regime of daily fluctuations, and increasing average base flows (Howard and Dolan, 1981; Topping and others, 2000, 2003). The consequences of these changes include the lack of sediment redistribution to the channel margins, including sediment deposition in the lower elevations of gullies (Hereford and others, 1993; Fairley, 2005; Wright and others, 2005). The lack of sediment-rich floods in the post-dam era is suspected to have increased gully erosion rates in the Grand Canyon (Hereford and others, 1993; Thompson and Potochnik, 2000; Fairley, 2003), and several studies are currently underway to explore how the presence and operations of Glen Canyon Dam may have affected erosion rates at archaeological sites along the Colorado River (for example, Collins and others, 2012; Sankey and Draut, 2014).

Gully erosion occurs when surface runoff during intense rainfall is localized in sufficient volumes to cut well-defined channels into unconsolidated surficial deposits. It is an important and sometimes dominant process of sediment loss in many watersheds, especially in arid and semi-arid regions (Valentin and others, 2005). Understanding gully erosion in the Grand Canyon is of particular interest to resource managers due to the negative impact of erosion on the integrity of archaeological sites within the Colorado River corridor. In 1990-91, 475 archaeological sites were documented between Glen Canyon Dam and Separation Canyon (river mile $240^{3}$ ) by the Grand Canyon River Corridor Survey Project (Fairley and others, 1994). Many of these sites are located on poorly consolidated alluvial terraces and aeolian dunes, and are actively being eroded by gully incision (Fairley and others, 1994; Leap and others, 2000; Fairley 2003, 2005). Although gully erosion is not a recent phenomenon in the Grand Canyon, gully erosion in the pre-dam era was partially offset by fine-sediment redistribution into gullies during annual spring runoff floods and migration of aeolian dunes into gully areas (McKee, 1938; Hereford and others, 1993; Sankey and Draut, 2014). In the post-dam era, the sediment load and magnitude of floods have been greatly reduced (Topping and others, 2003), along with the redistribution of flood sands by wind (Draut and Rubin, 2008; Draut, 2012); the degree to which these changes affect the preservation of irreplaceable archaeological resources in the Grand Canyon is a subject of on-going investigations (for example, Collins and others, 2009, 2012; Fairley and others, 2012; Sankey and Draut, 2014).

To help alleviate effects of the reduced sediment redistribution potential of the Colorado River downstream of Glen Canyon Dam, the Operation of Glen Canyon Dam Final Environmental Impact Statement and Record of Decision included the proposal to use experimental high flows, termed beach/habitat-building flows, to redistribute sand from the river channel bottom to higher elevations along the river margins (U.S. Department of the Interior, 1995, 1996). The preservation of cultural resources also was linked to the potential for future high flows to deposit fresh or renewed sand deposition in established gullies (Hereford and others, 1993). It was hypothesized that redistribution of sediment from the channel of the Colorado River to the mouths of gullies by beach/habitat-building flows (also referred to as High-Flow Experiments) would potentially slow or lessen gully incision rates, reducing impacts to archaeological sites (Hereford and others, 1993; Yeatts, 1996; Thompson and Potochnik, 2000).

\footnotetext{
${ }^{3}$ Because of its historical precedence, river mile is used to describe locations along the Colorado River. River miles are measured downstream of Lees Ferry (fig. 1), along the centerline of the Colorado River.
} 


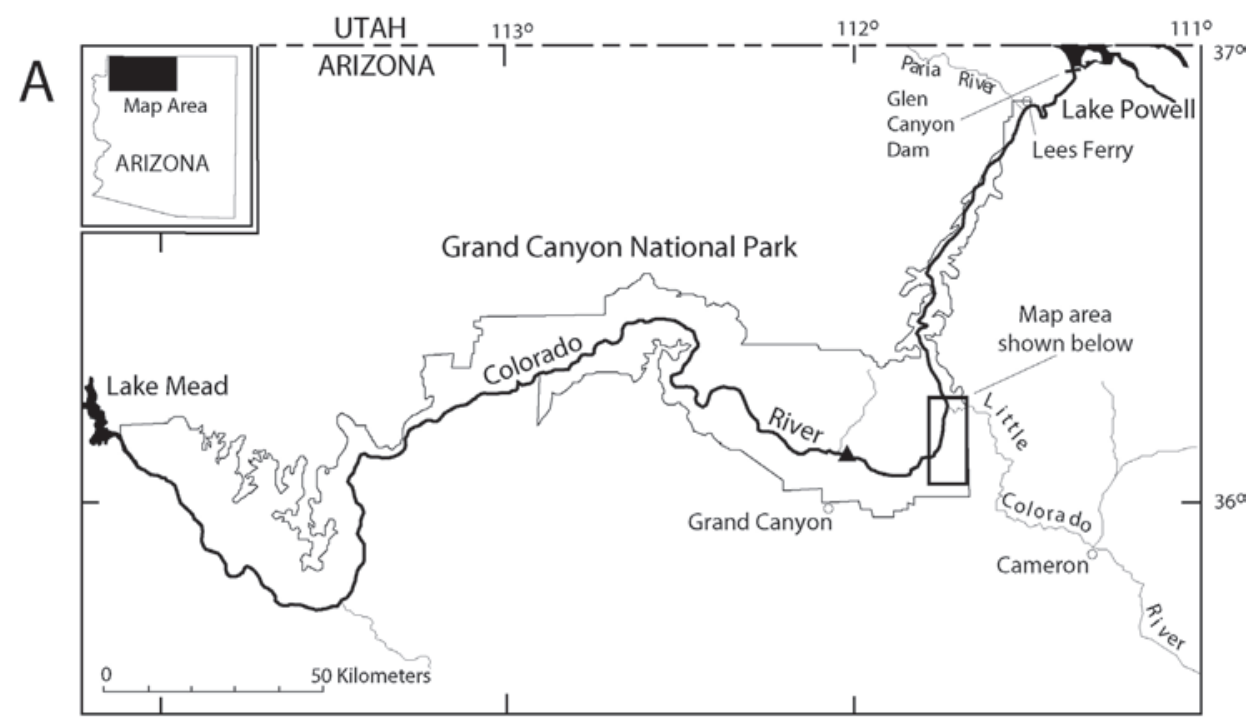

B

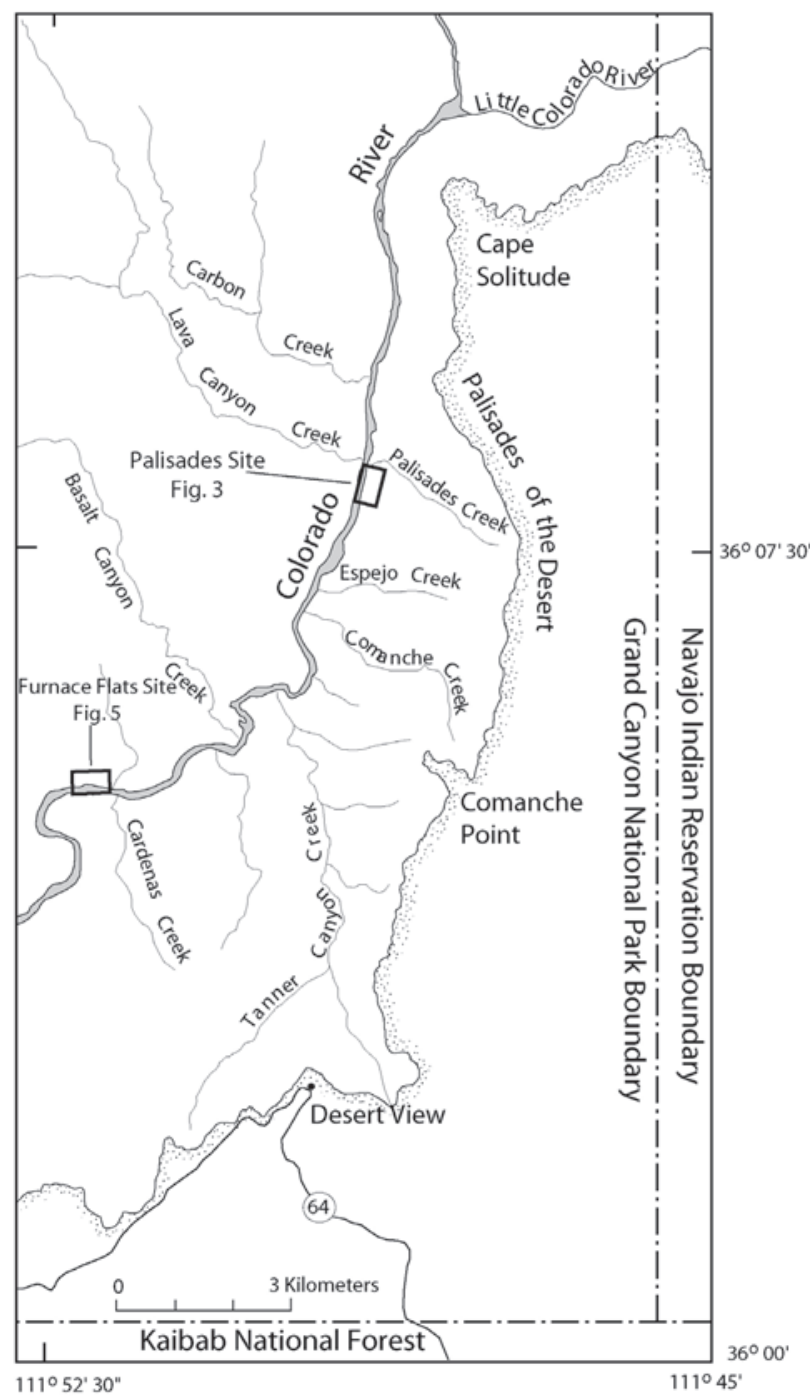

Figure 1. Map showing (A) general location of study area within the Grand Canyon National Park, Arizona and (B) the two specific study areas in the eastern Grand Canyon National Park, Arizona. 


\section{High-Flow Experiments}

Prior to 2008, there were two high-flow experiments (HFEs) (Melis, 2011; Melis and others, 2011). The first HFE was a 7-day release of $1,274 \mathrm{~m}^{3} / \mathrm{s}$ in March 1996 (Webb and others, 1999). The second HFE was a 60-hour peak release of $1,175 \mathrm{~m} / \mathrm{s}$ in November 2004 (2004 HFE) (Topping and others, 2006). The 2008 HFE involved another 60-hour release with a peak discharge of 1,203 m³ in March 2008 (Melis and others, 2011). Since completion of the study described in this report, there have been two additional HFEs, one in November 2012 and another in November 2013, with peak discharges of 1,269 and 1,048 $\mathrm{m}^{3} / \mathrm{s}$, respectively (http://www.gcmrc.gov/discharge_qw_sediment/station/GCDAMP/09380000). The magnitude of discharge during the highest HFEs is approximately twice the peak discharge from Glen Canyon Dam under normal operations, and about one-half of the 2-year recurrence peak flow of the unregulated Colorado River (Topping and others, 2003).

\section{Purpose and Scope}

This study addresses two primary topics. First, we document the effects of the 2008 HFE on three individual gullies in the eastern Grand Canyon by comparing results of gully surveys obtained before and after the 2008 HFE. Second, we compare the results of the 2008 gully surveys to older surveys dating back to 1996, as well as to one gully survey conducted in April 2010. With this 12 to 14 year dataset, we are able to make observations about the evolution of gullies in the Grand Canyon on a decadal timescale and to explore implications for archaeological resource preservation at these sites. In addition to the two primary study goals, we also assess the total station survey methodology used in this and other studies. Finally, we discuss management implications of our findings and suggest ideas for future research.

\section{Background}

Because of their size and proximity to known archaeological sites, two gullies located in the eastern Grand Canyon near Palisades Creek have received considerable attention from previous researchers (see Hereford and others, 1993; Hereford, 1996; Yeatts, 1996, 1998; Hazel and others 2000, 2008a; Pederson and others 2003, 2006; Draut and others, 2005; Collins and others, 2009, 2012). Hereford (1996) provided evidence indicating that two incipient gullies began incising the alluvial terrace at Palisades prior to 1965. Comparison of aerial photographs taken in 1965 and 1973 show the two gullies at the Palisades site to be stable, both terminating on the pre-dam terrace alluvium and not directly integrated with the Colorado River (Hereford, 1996). By October 1984, however, aerial photographs indicate substantial erosion at the two gullies, herein referred to as the Palisades North and South gullies. The photographs show that both the north and south gullies lengthened by 80 and $100 \mathrm{~m}$, respectively, linking both channels directly to the Colorado River (Hereford, 1996). The marked incision was attributed to a period of unusually high rainfall that occurred between 1978 and 1984 (Hereford and others, 1993; Hereford, 1996). 
Hereford and others (1993) hypothesized that, in the pre-dam era, runoff from gully mouths would rapidly lose velocity and spread out to form small, low-gradient alluvial fans as it flowed unconfined over the porous, permeable sand of essentially horizontal terraces (Hereford, 1996). Prior to dam closure, annual overtopping of pre-dam terraces by the spring snowmelt flood "removed any previously formed alluvial fans and filled incipient channels through deposition and partial erosion of the terrace," thus maintaining a constant "effective base level" 3-4 m above typical post-dam era flows (Hereford, 1996, p. 6). Hereford and others (1993) suggested that Glen Canyon Dam operations exacerbated gully erosion as the former terrace-based gullies became integrated with the Colorado River and adjusted to the lower effective base level of typical postdam flows in the absence of large floods (fig. 2). Thompson and Potochnik (2000) hypothesized that the HFE-deposited sediment in and around gully mouths could help mitigate gully erosion by backfilling gully mouths and increasing the amount of sand available for aeolian migration into upper portions of gullies.

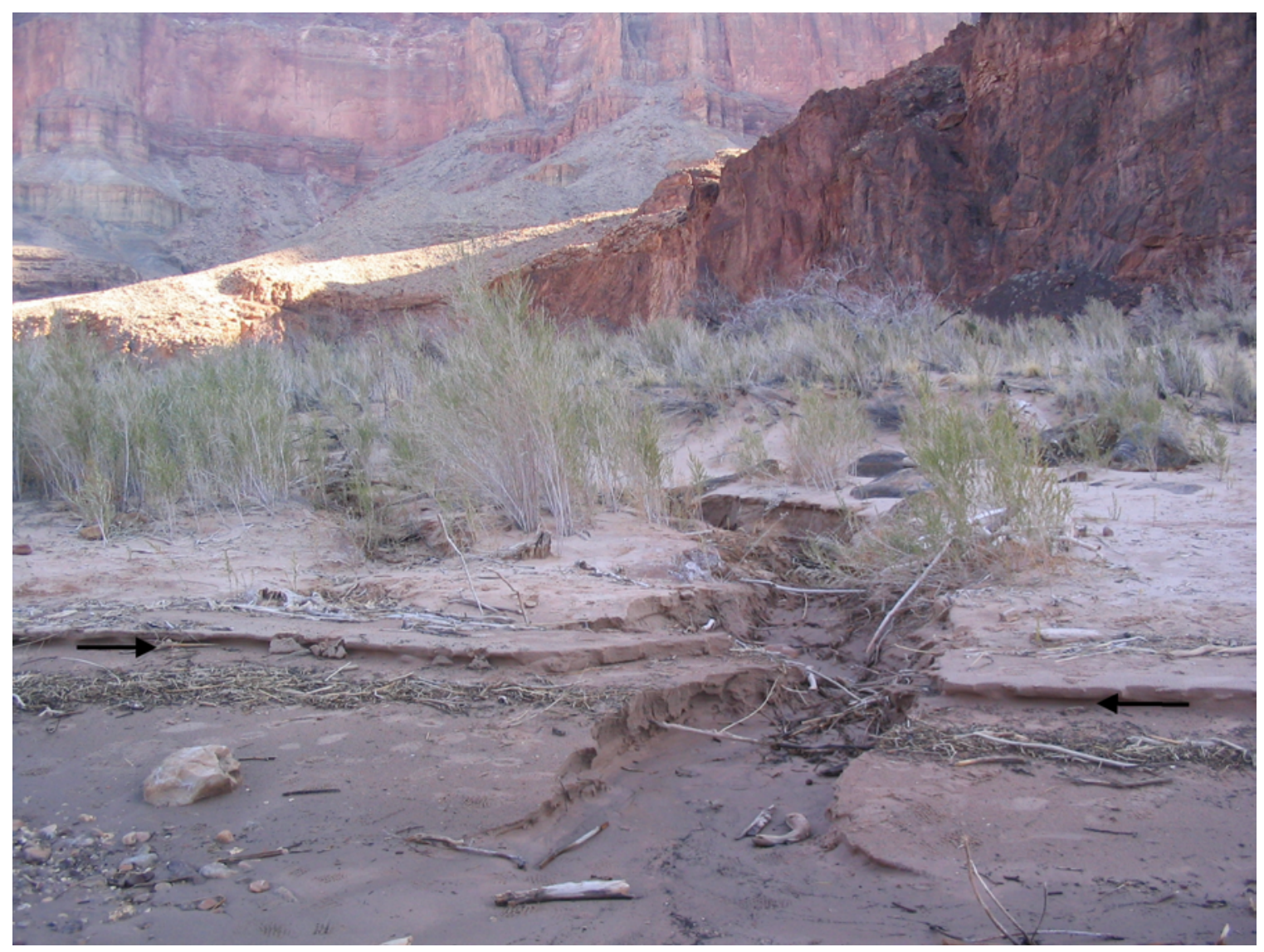

Figure 2. Photograph showing mouth of the Palisades South gully, Grand Canyon National Park, Arizona, February 9,2008. View is to the northwest. Black arrows indicate a typical base flow of the Colorado River in the post-dam era of 351 cubic meters per second. Photograph by J. Hazel, Northern Arizona University. 
Investigating sediment deposition after the 1996 HFE, Yeatts (1996) found that sediment was deposited in gully mouths at three out of the four sites he studied, including the Palisades site. The sediment deposited by the 1996 HFE persisted for several years (Yeatts, 1998; Hazel and others, 2000). Hazel and others (2008a) described gully evolution in the mouth of the Palisades South gully between 1996 and 2005. They reported significant erosion between 1996 and 2004 (approximately $63 \mathrm{~m}^{3}$ ), net deposition during the $2004 \mathrm{HFE}$ (approximately $10 \mathrm{~m}^{3}$ ), and minor erosion between the 2004 HFE and May 2005. Neither Yeatts $(1996,1998)$ nor Hazel and others (2008a) were able to determine if HFE-deposited sediment had any effect on gully incision rates in the upper reaches of the gully.

Approaching the topic from a different angle, Wiele and Torrizo (2005) applied numerical modeling methods to simulate deposition near archaeologically sensitive areas under variable flow and sediment supply conditions. Their study focused on four short reaches of the Colorado River between river miles 66 and 70, including the two study areas discussed in this report. Their modeling results showed significant variability in deposition volumes related to channel shape, as well as to discharge and sand supply. They found that in two reaches, including the Palisades reach, sand deposition increased with stage and sand supply, but this pattern was not evident in the other two reaches. They concluded that trends in sand storage were more predictable in the reaches dominated by recirculation zones, such as the Palisades reach, than in reaches where sand storage is dependent on small-scale variations in channel margin morphology, such as in Upper Unkar reach, which includes the Furnace Flats gully site discussed in this report where the river is relatively wide (Wiele and Torrizo, 2005).

Since 1995, the National Park Service has been installing and maintaining rock and brush check dams at selected gullies within and in close proximity to known archaeological sites, including the Palisades site (Leap and Coder, 1995). Direct measurements by Hazel and others (2008a) in 2004 indicated that in-channel flow had destroyed four check dams installed in the Palisades South gully in the late 1990s. Pederson and others $(2003,2006)$ investigated the effectiveness of check dams and other erosion-control structures (ECS) at Palisades and eight other sites. They concluded that ECS do reduce erosion if they are actively maintained and that brush check dams are more effective than rock check dams and result in less damage when breached; however, in all cases, damaged check dams exacerbate gully erosion. In an ongoing study at several archaeological sites, the use of terrestrial lidar techniques for monitoring gully erosion in the Grand Canyon National Park is being investigated to track larger landscape-level changes at archaeological sites (Collins and others, 2009, 2012); these studies show that deposition behind ECS can be detected using repeat lidar measurements (Collins and others, 2009).

Addressing the hypothesis that HFEs can reduce gully erosion by increasing sources of sediment for aeolian migration into gully areas, Draut and Rubin (2008) and Draut and others (2009a, 2009b, 2010) described weather and aeolian sand-transport data at the Palisades site between 2004 and 2009. The 2008 weather station data showed that although the flood-formed sandbar riverward (southwest) of the study sites was enlarged substantially during the $2008 \mathrm{HFE}$, the dominant wind direction did not move sand from the sandbar into the dune field (Draut and others, 2009b). The dominant wind direction in 2008 was similar to conditions measured in previous years (Draut and Rubin, 2008; Draut and others, 2009a, 2009b). 


\section{Study Site Descriptions}

The three gullies examined in this report are all located within the Furnace Flats geomorphic reach of the eastern Grand Canyon described by Schmidt and Graf (1990). The greatest concentration of archeological sites in the Grand Canyon National Park occur within this geomorphic reach (approximate river miles 62 to 77), averaging more than five sites per kilometer (Fairley and others, 1994). Downstream of the Palisades fault near river mile 66, the Furnace Flats reach is characterized by a relatively wide and shallow river channel. Hereford and others (1993) identified and mapped a number of Holocene stream terraces consisting of sandy alluvium that are locally interbedded with aeolian sand and gravelly colluvium in this reach. Based on radiocarbon dating and archeological artifacts, these terraces formed between 770 B.C. and A.D. 1890 (Hereford and others, 1996). Bedrock geology of the reach was mapped and described by Huntoon and others (1986). The surficial geology of the immediate area was mapped and described by Hereford (1996). Additional work on the local terrace sedimentology is described by Draut and others (2005).

The three gullies discussed in this report occur within two study areas - the Palisades Site and the Furnace Flats Site (fig. 1). The Palisades Site includes two gullies which are referred to as the Palisades South Gully and the Palisades North Gully, respectively. Collectively, these two gullies comprise the Palisades Gully Network. The third gully is located in the Furnace Flats Site and is simply referred to as the Furnace Flats Gully.

\section{Palisades Gully Network}

The Palisades study area encompasses two adjacent gullies located on river left (as viewed in a downstream direction) at river mile 66.1 (fig. 3). Both gullies are located on the downstream side of a large debris fan extending from the mouth of Palisades Creek. This large, low-gradient debris fan creates a zone of recirculating water (eddy) downstream of the debris fan. A complete description of the Palisades gully network, including catchment area and vegetative cover, is provided by Pederson and others (2003).

The larger of the two gullies is the downstream, southernmost gully. This gully is more than $300 \mathrm{~m}$ in length and is approximately $1.5 \mathrm{~m}$ deep near the confluence with the Colorado River. Using the convention established by Pederson and others (2003), this gully is referred to as the Palisades South gully. The upstream gully, herein referred to as the Palisades North gully, is slightly more than $100 \mathrm{~m}$ in length and less than $0.75 \mathrm{~m}$ deep at its deepest point. Erosion- control structures, including rock and brush check-dams, rock armoring and other bank stabilization efforts, are present in both of these gullies (fig. 4). 


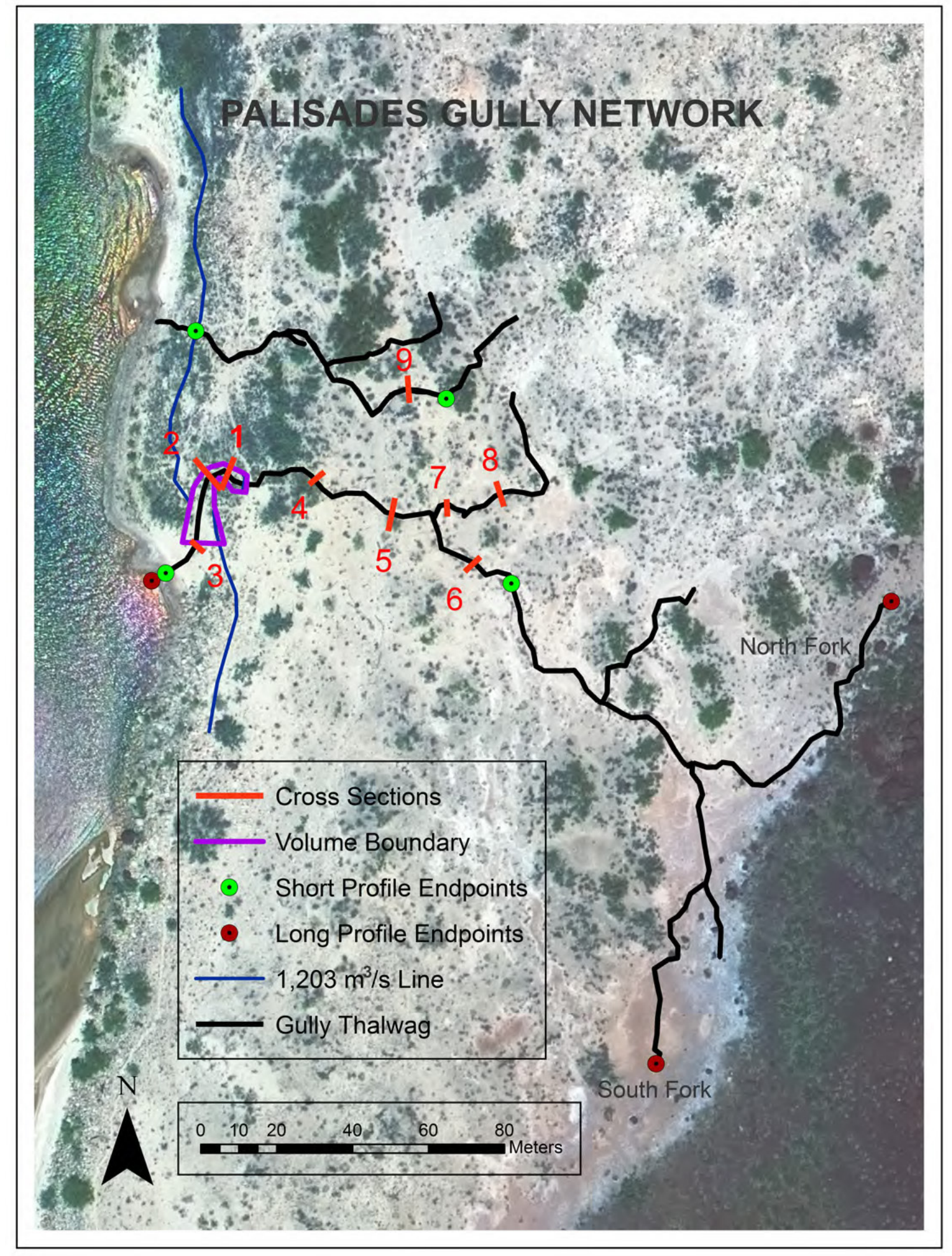

Figure 3. Aerial photograph showing Palisades study area, Grand Canyon National Park, Arizona, May 2002. Volume boundary was used to calculate volume changes within the gully mouth. The Colorado River is on the left and is flowing from north to south. 

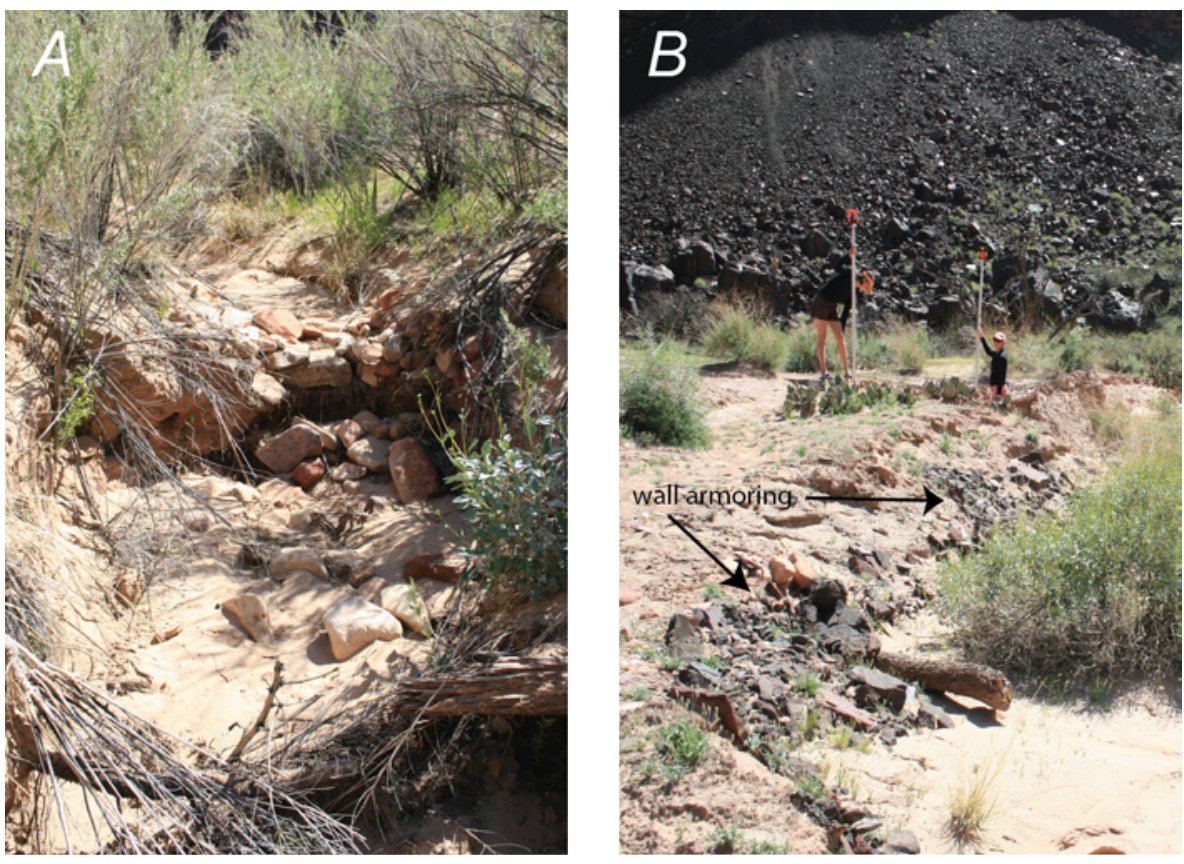

Figure 4. Photographs showing examples of erosion control structures constructed to reduce gully erosion at the Palisades South gully. $(A)$ A rock check dam; $(B)$ Wall armoring. View for both photographs is to the east. Photographs by J. Hazel, Northern Arizona University, April 1, 2008.

\section{Furnace Flats Gully}

The third gully studied in this paper is located on river right at river mile 71.9 (fig. 5). Yeatts (1996) examined this site because it was an actively eroding gully, located in proximity to but not within known cultural sites. Although there are several gullies in this area, we report only on the gully called Furnace Flats \#1 by Yeatts $(1996,1998)$ and Hazel and others $(2000)$, herein referred to as the Furnace Flats gully. This gully is approximately $35 \mathrm{~m}$ long, $1 \mathrm{~m}$ wide, and $0.5 \mathrm{~m}$ deep, and has not been altered by ECS stabilization efforts.

In contrast to the Palisades gully network, which has part of the catchment area located on a tributary debris fan, the Furnace Flats gully has incised into an alluvial terrace that slopes up to an outcrop of Precambrian Dox Sandstone bedrock close to the Colorado River. The alluvial terrace consists of unconsolidated fine-grained, silty sand that was likely deposited as a channel margin bar due to bank irregularities that create minor flow obstructions at high water (Hazel and others, 2000; Wiele and Torrizo, 2005). 


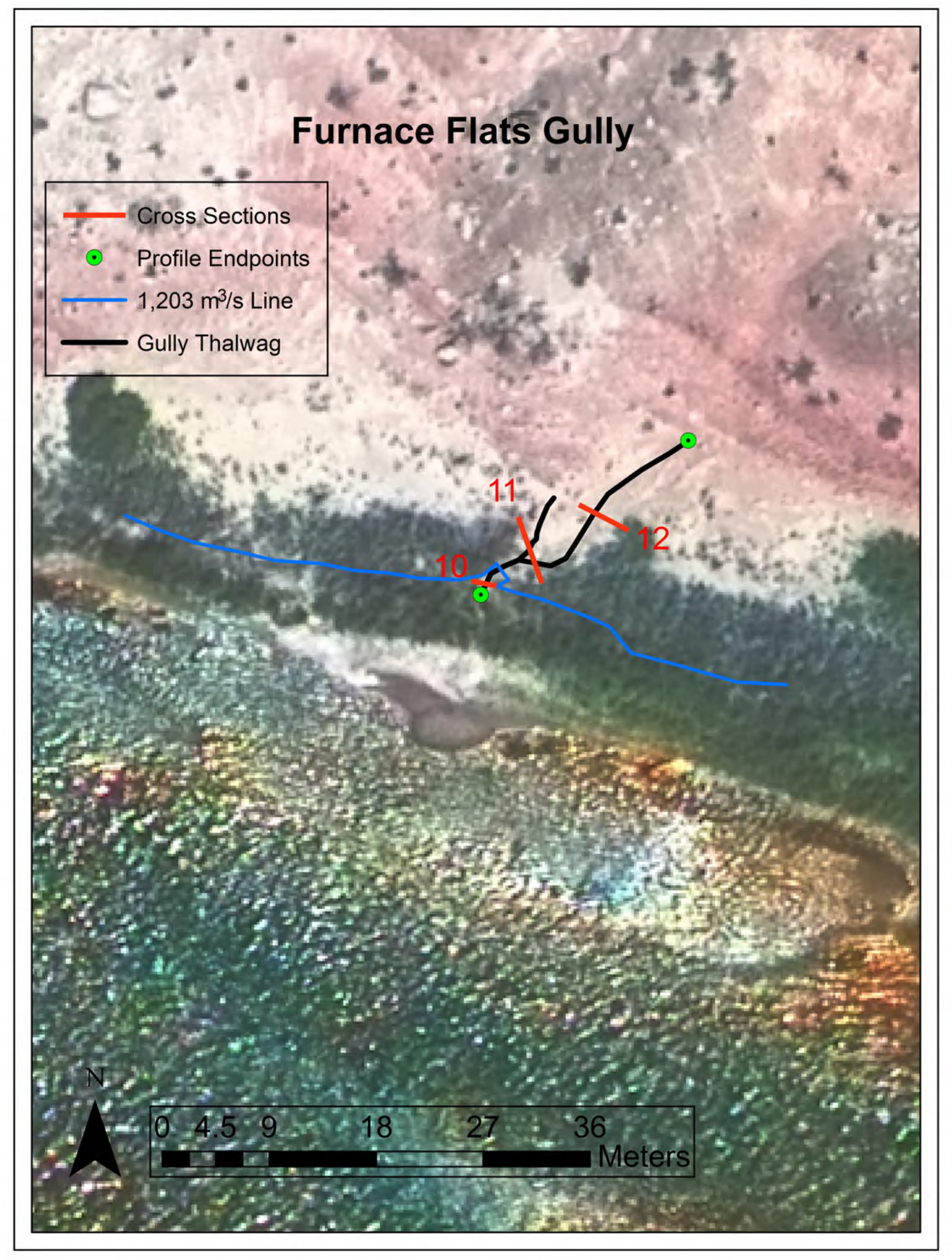

Figure 5. Aerial photograph showing Furnace Flats gully, Grand Canyon National Park, May 2002. The 1,203 $\mathrm{m}^{3} / \mathrm{s}$ line is the high water mark of the 2008 high-flow experiment. The Colorado River flows from east to west. 


\section{Methods}

In order to quantify sediment deposition in gully mouths as well as other potential geomorphological changes associated with the 2008 HFE, surveys of the gully thalwegs, gully walls and immediately adjacent topography were completed in February 2008 and again in April 2008 with electronic (optical) total stations, similar to previous studies at the sites (see Yeatts, 1996; Hazel and others, 2000, 2008a). Pre-HFE surveys of the South and North Palisades gullies occurred on February 9, 2008. A pre-HFE survey of the Furnace Flats gully took place on February 10, but due to technical problems, most of those data were not recoverable. Post-HFE surveys took place on April 4, 2008, at the two Palisades gullies and April 5, 2008, at the Furnace Flats gully. On April 15, 2010, a third round of survey at only the Palisades South Gully was completed.

Field surveys were conducted to define gully mouth topography in the area between the river's edge and the elevations reached by flows in excess of approximately $1,700 \mathrm{~m}^{3} / \mathrm{s}$. Above this elevation, data collection was limited to a profile of the gully thalweg. Inter-gully areas were not surveyed in 2008 or 2010 . An accuracy of $\pm 0.05 \mathrm{~m}$ was identified as the minimum horizontal and vertical precision of total station acquired ground points (Hazel and others, 2008b). Survey accuracy was maintained by horizontal and vertical checks for positional error between known reference points in the Grand Canyon Monitoring and Research Center's control network. Positions are referenced to NAD83(NSR2007) and projected to the 1983 State Plane Coordinate System, Arizona Central Zone (0202) grid. To allow for comparisons, all older survey data were converted to this common datum by Hazel and others (2008a). Water elevations reached by the Colorado River during the 2008 HFE and other flow events were based on established stage relations between discharge measured at USGS gaging stations and previously surveyed water-surface elevations and flood-debris strand lines (Hazel and others, 2006). In general, survey data were collected with a feature-based methodology using break lines to define distinct changes in slope (for example, gully walls), lines of equal elevation (that is, high water marks), and along the gully thalweg.

Where sufficient gully topography was collected, the gully topography was modeled using the triangulated irregular network (TIN) method for surface modeling using survey-grade computer software. Changes in deposit volumes were calculated using direct TIN-to-TIN comparisons. These calculations were made at the mouth of the Palisades South gully. As previously described in Hazel and others (2008a), point density was about one point per $0.75 \mathrm{~m}^{2}$ in the gully mouth areas. Because of changes to the gully mouth area, the volume boundary used by Hazel and others (2008a) was modified to fit the 2008 and 2010 data. All volume changes presented in table 2 use the modified volume boundary. In addition, cross sections were generated from the TINs at the same locations examined by Hazel and others (2008a). The cross-section endpoints at the Palisades site were originally established by the National Park Service in 1998.

We compared gully thalweg profiles using the normalized profile method devised by Pederson and others (2003) and adopted by Hazel and others (2008a). Although previous surveys concentrated efforts on collecting gully thalweg profiles, different researchers collected gully thalweg data at differing point densities (table 1). Additionally, thalweg sinuosity may change between surveys as the gully responds to various factors such as the installation or breaching of check-dams. Because of these inconsistencies, difficulties arise in comparing gully thalweg profiles collected by different researchers at different times. The normalized profile method utilizes two fixed endpoints common to all surveys being compared. Endpoints used in this study are shown in figures 3 and 5. By normalizing the distance of each thalweg profile survey point from the upper endpoint, all thalweg profiles can be plotted along a common x-axis. At the Palisades South gully, 
two different sets of endpoints were used; the short profile compares recent thalweg profiles to data dating back to January 1998, whereas the long profile highlights gully thalweg evolution between 2004 and 2010 at the upper reaches of the Palisades South gully.

Table 1. Topographic surveys conducted at the Palisades South gully network, Grand Canyon National Park, Arizona.

[Modified from Hazel and others, 2008a. Survey Description: Discharge elevation determined from a stage-discharge relation partly based on surveyed elevations of driftwood logs inferred to represent historical flood strandlines (Draut and others, 2005). NC, data not collected; $\mathrm{m}^{3} / \mathrm{s}$, cubic meters per second; $\mathrm{pts} / \mathrm{m}$, points per meter]

\begin{tabular}{|c|c|c|c|}
\hline Survey date & Source & Survey description & $\begin{array}{c}\text { Profile point density } \\
\text { (pts } / \mathrm{m})\end{array}$ \\
\hline 02-17-1996 & Yeatts, 1996 & Site topography to $1,700 \mathrm{~m}^{3} / \mathrm{s}$ & $\mathrm{NC}$ \\
\hline 05-12-1996 & Yeatts, 1996 & Site topography up to $1,700 \mathrm{~m}^{3} / \mathrm{s}$ & $\mathrm{NC}$ \\
\hline 02-28-1998 & $\begin{array}{l}\text { Grand Canyon National Park, K. } \\
\text { Kohl, USGS, written commun., } \\
2006\end{array}$ & $\begin{array}{l}\text { Thalwegs, cross sections, and } \\
\text { check dams }\end{array}$ & 0.40 \\
\hline 10-14-1998 & Hazel and others, 2000 & Site topography up to $2,000 \mathrm{~m}^{3} / \mathrm{s}$ & 0.39 \\
\hline 10-7-1999 & Hazel and others, 2000 & Site topography up to $2,000 \mathrm{~m}^{3} / \mathrm{s}$ & 0.59 \\
\hline $09-27-2002$ & Pederson and others, 2003 & Thalweg profiles and check dams & 1.02 \\
\hline $11-11-2003$ & $\begin{array}{l}\text { K. Brown, USGS, written } \\
\text { commun., } 2006\end{array}$ & Thalweg profiles & 0.37 \\
\hline $11-20-2004$ & Hazel and others, 2008a & Gully topography up to $4,500 \mathrm{~m}^{3} / \mathrm{s}$ & 0.52 \\
\hline $12-10-2004$ & Hazel and others, 2008a & Gully topography up to $4,500 \mathrm{~m}^{3} / \mathrm{s}$ & 0.42 \\
\hline $05-13-2005$ & Hazel and others, $2008 \mathrm{a}$ & Site topography up to $4,500 \mathrm{~m}^{3} / \mathrm{s}$ & 0.43 \\
\hline 02-09-2008 & This study & $\begin{array}{l}\text { Site topography up to } 1,700 \mathrm{~m}^{3} / \mathrm{s} \\
\text { Thalweg profile up to } 4,500 \mathrm{~m}^{3} / \mathrm{s}\end{array}$ & 0.34 \\
\hline 04-04-2008 & This study & $\begin{array}{l}\text { Site topography up to } 1,700 \mathrm{~m}^{3} / \mathrm{s} \\
\text { Thalweg profile up to } 4,500 \mathrm{~m}^{3} / \mathrm{s}\end{array}$ & 0.28 \\
\hline $04-15-2010$ & This study & $\begin{array}{l}\text { Site topography up to } 1,700 \mathrm{~m}^{3} / \mathrm{s} \\
\text { Thalweg profile up to } 4,500 \mathrm{~m}^{3} / \mathrm{s}\end{array}$ & 0.46 \\
\hline
\end{tabular}




\section{Results}

\section{Changes as a Result of the 2008 High-Flow Experiment}

The 2008 HFE resulted in $12 \mathrm{~m}^{3}$ of deposition and $11 \mathrm{~m}^{3}$ of erosion resulting in net deposition of $1 \mathrm{~m}^{3}$ of sediment in the predefined mouth area of the Palisades South gully during the 2008 HFE (volume boundary shown in fig. 3). Net deposition from the 2008 HFE was less than the $10 \mathrm{~m}^{3}$ of deposition attributed to the $2004 \mathrm{HFE}$, but greater than the $1 \mathrm{~m}^{3}$ of erosion measured after the 1996 HFE (table 2). Surface elevations within the mouth of the Palisades South gully increased by as much as $0.6 \mathrm{~m}$ (figs. $6 \mathrm{E}, 7 \mathrm{~B}$, and $8 \mathrm{C}$ )

In addition to depositing sediment in the mouth of the Palisades South gully, the 2008 HFE significantly reshaped and widened the mouth area (figs. 6 and 7). Cross sections located in the upper elevations of the Palisades South gully mouth indicate gully widening of $0.5-1 \mathrm{~m}$ within the gully mouth (figs. 8A and 8B).

Table 2. Volume of scour and fill in the mouth of the Palisades South gully for the three high-flow experiments (HFE) and the intervals in between.

$\left[\mathrm{m}^{3}\right.$, cubic meters $]$

\begin{tabular}{lcccc}
\hline \multicolumn{1}{c}{ Survey dates } & $\begin{array}{c}\text { Comparison } \\
\text { interval } \\
(\text { days })\end{array}$ & $\begin{array}{c}\text { Scour } \\
\left(\mathbf{m}^{3}\right)\end{array}$ & $\begin{array}{c}\text { Fill } \\
\left(\mathbf{m}^{3}\right)\end{array}$ & $\begin{array}{c}\text { Net change } \\
\left(\mathbf{m}^{3}\right)\end{array}$ \\
\hline $\begin{array}{l}\text { Feb. 1996-May 1996 } \\
(1996 \text { HFE) }\end{array}$ & 85 & 9 & 8 & -1 \\
May 1996-Nov. 2004 & 3,114 & 66 & 3 & -63 \\
$\begin{array}{l}\text { Nov. 2004-Dec. 2004 } \\
\text { (2004 HFE) }\end{array}$ & 20 & 13 & 23 & 10 \\
$\begin{array}{l}\text { Dec. 2004-Feb. 2008 } \\
\text { Feb. 2008-April 2008 }\end{array}$ & 1,157 & 13 & 7 & -5 \\
(2008 HFE) & 54 & 11 & 12 & 1 \\
April 2008-April 2010 & 741 & 17 & 7 & -10 \\
\hline
\end{tabular}



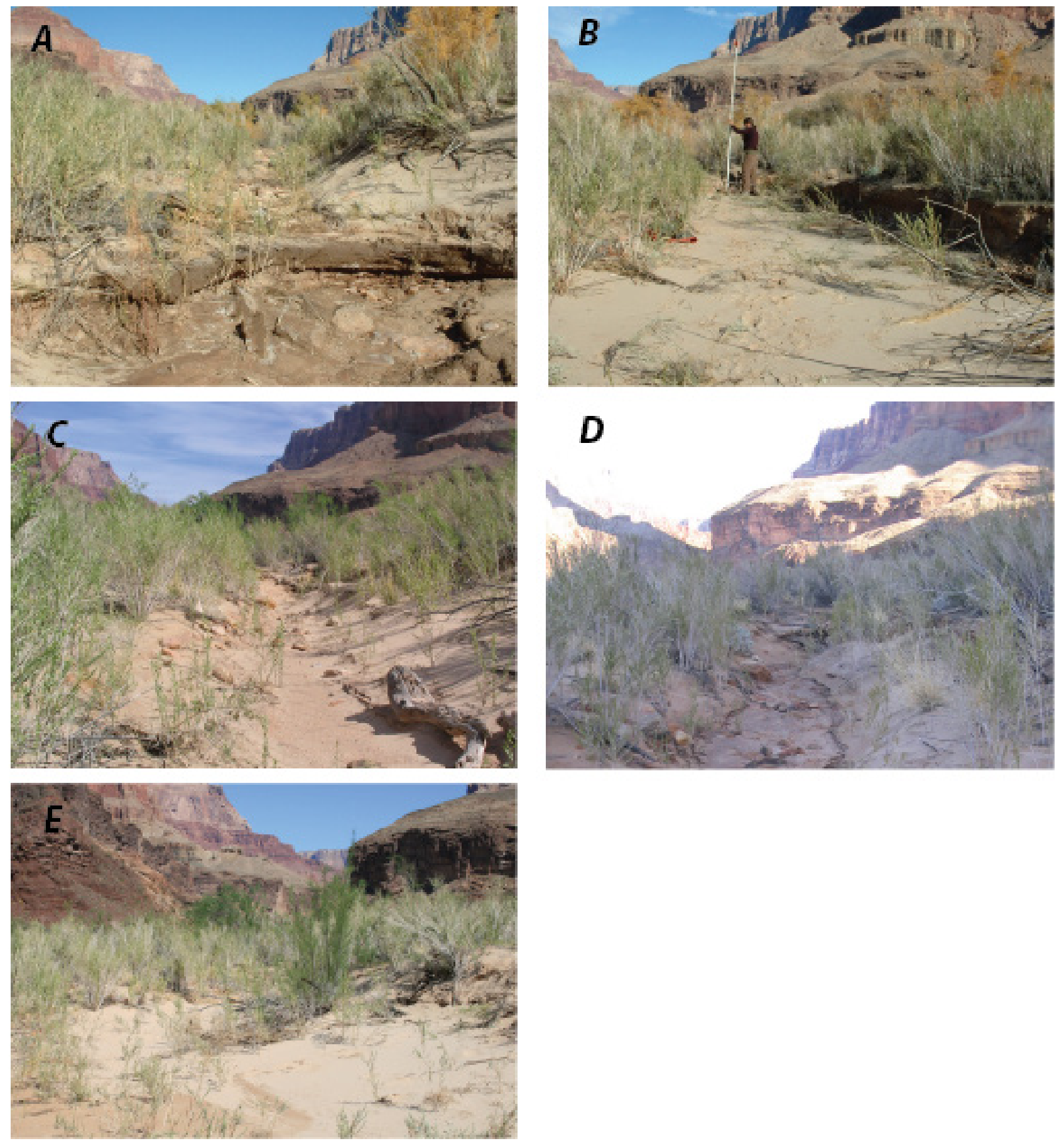

Figure 6. Selected repeat photographs showing the Palisades South gully as viewed looking northeast from the terminus near the Colorado River. (A) The gully area mouth as it appeared on November 20, 2004; (B) deposition in the gully bottom on December 10, 2004, as a result of the 2004 high-flow experiment; (C) gully mouth area as it appeared on April 19, 2007; (D) evidence of recent surface flow in the gully bottom (photograph taken on February 9, 2008); (E) deposition in the gully bottom on April 4, 2008, as a result of the 2008 high-flow experiment. Photographs 6A and 6B by A. East; U.S. Geological Survey; photographs 6C-6E by J. Hazel, Northern Arizona University. 

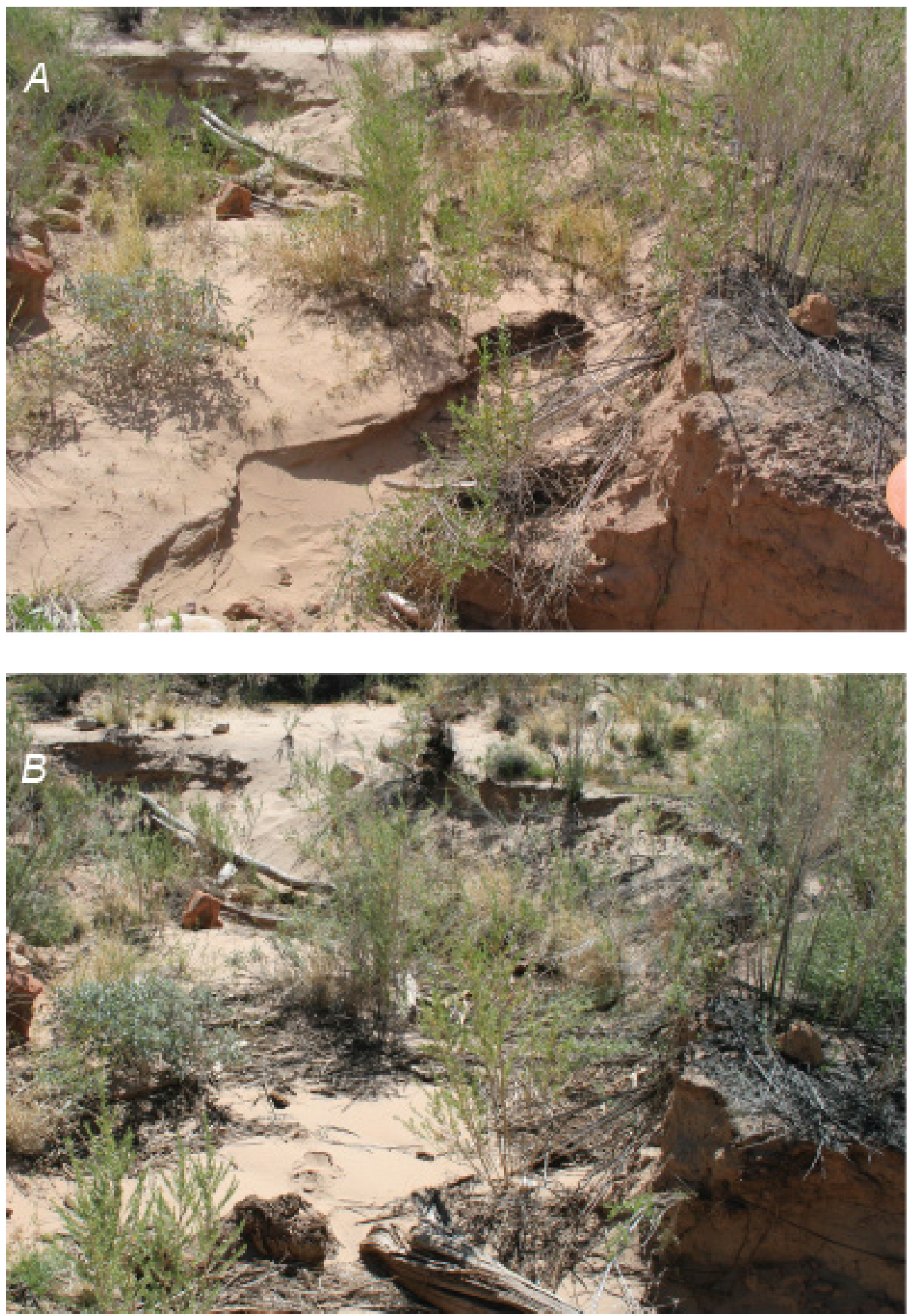

Figure 7. Repeat photographs showing Palisades South gully upper mouth area from (A) April 19, 2007, 11 months prior to the 2008 high-flow experiment and $(B)$ April 4, 2008, just after the 2008 high- flow experiment. View is to the east. Effects of the 2008 high-flow experiment, including infilling of the gully thalweg and gully widening along the southern wall, can be observed. Photographs by J. Hazel, Northern Arizona University. 

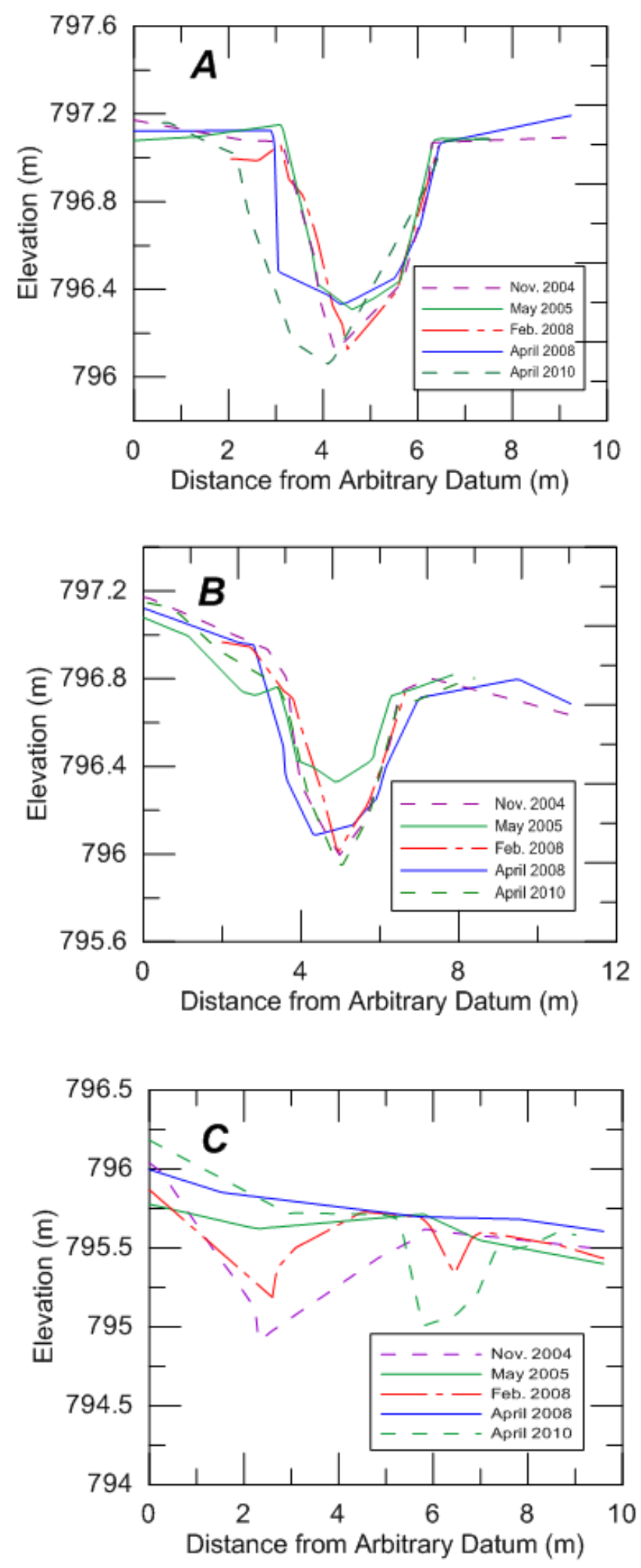

Figure 8. Cross sections across the mouth of the Palisades South gully, Grand Canyon National Park, Arizona. $(A)$ Cross section $1 ;(B)$ cross section 2; and $(C)$ cross section 3. All cross section locations are shown in figure 3 and are viewed in a down-gully direction. 
The weather station located near the Palisades site indicates that the largest rainfall event between February 9 and April 4, 2008, occurred on February 22, 2008, with $16.5 \mathrm{~mm}$ of precipitation in less than 24 hours (Draut and others, 2009a). We believe that this amount or any of the lesser precipitation events that occurred between our February and April surveys were insufficient to produce surface flow in the gully network. Therefore, we attribute all change in the Palisades South gully between February 9 and April 4, 2008, to the 2008 HFE.

Because the Palisades North gully did not contain a discernible mouth area with measurable walls, only the thalweg profile was collected. Analysis of the Palisades North gully thalweg profile indicates no significant change between February and April 2008 (fig. 9). This result is consistent with the findings in Hazel and others' (2008a) report, which documented that the Palisades North gully was largely unaffected by both the 1996 and 2004 HFEs.

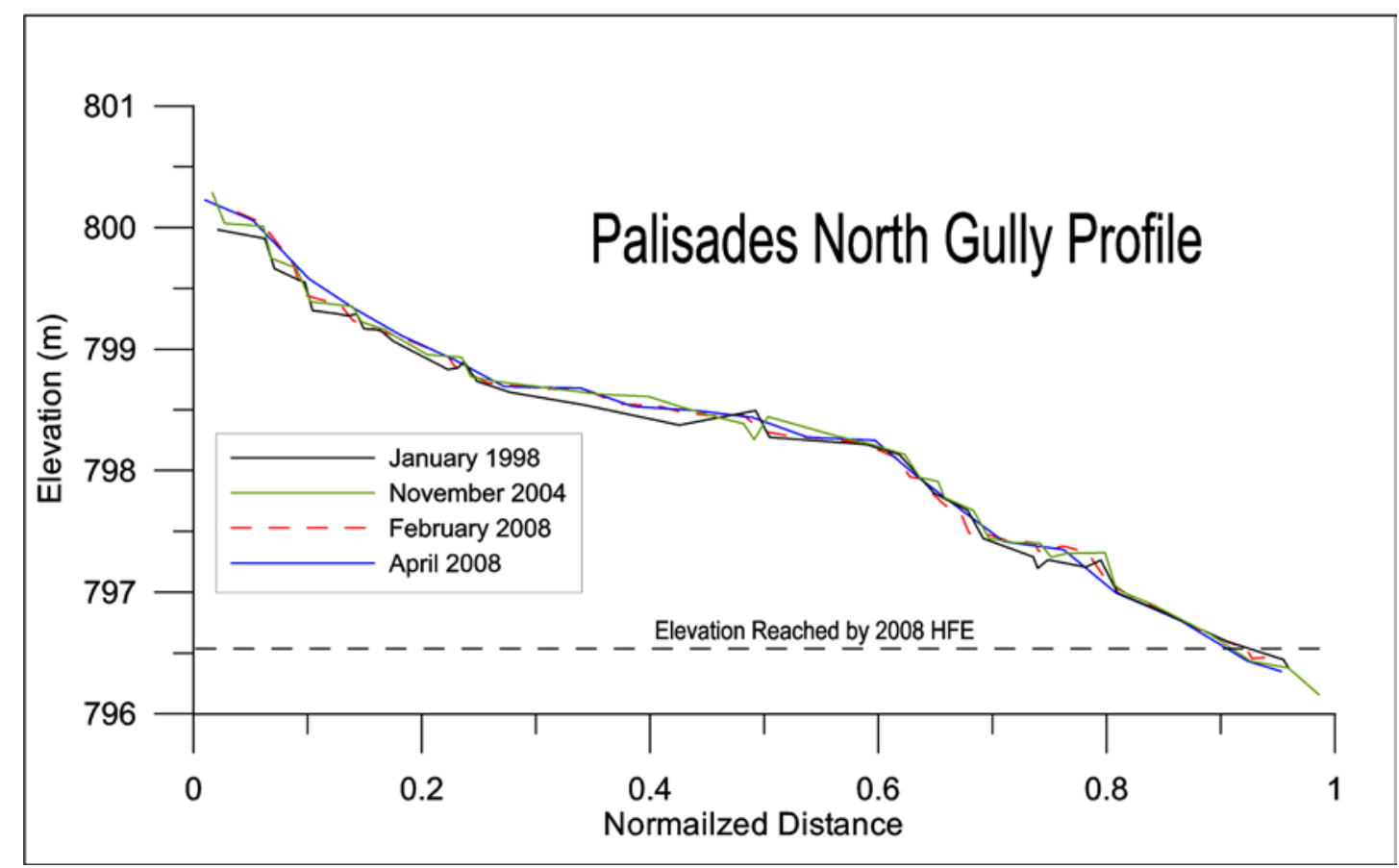

Figure 9. Normalized profile of the Palisades North gully, Grand Canyon National Park, Arizona, 1998-2010. Profile endpoints are shown in figure 3. Profile length between endpoints is approximately 86 meters. 
Because most of the data collected at the Furnace Flats gully prior to the 2008 HFE was not recoverable due to a technical problem with the data logger, our analysis of sediment deposition within the gully mouth is limited to one cross section located near the confluence with the Colorado River (cross section 10) (fig. 10A). Cross section 10 shows that the gully thalweg was buried by 0.3 $\mathrm{m}$ of flood-derived fine sediment.

\section{Gully Thalweg Evolution}

Gully thalweg evolution between 2004 and 2010 of the entire $308 \mathrm{~m}$ length of Palisades South gully, including the two main tributaries, is shown in figure 11. The 2004 thalweg profiles were collected at an average spacing of 1 point per 2.8 meters $(\mathrm{pt} / \mathrm{m})$, whereas the 2008 thalweg profile has a coarser spacing of $1 \mathrm{pt} / 3.6 \mathrm{~m}$. The April 2010 thalweg data were collected at the highest density, with an average spacing of $1 \mathrm{pt} / 2.2 \mathrm{~m}$. At elevations above those reached by the 2004 HFE, no discernible change can be detected between the February 2004 and April 2010 surveys of the gully thalweg. The variance in thalweg profiles is likely attributable to differences in point spacing between the surveys. Interpretation is further complicated by evidence of gully widening over this same time period (described in the next section, "Channel Widening"), as well as continued ECS maintenance by National Park Service personnel in March 2005 (Dierker and Leap, 2006), and possibly at other times not reported.

Prior to 2004, detailed topographic surveys were focused on the lowest $\sim 150 \mathrm{~m}$ of the Palisades South gully. Gully evolution between January 1998 and April 2010 of the lowest $\sim 135 \mathrm{~m}$ of the Palisades South gully is shown in figure 12. Comparison of the surveys shows as much as $0.8 \mathrm{~m}$ of thalweg incision between 1998 and 2010 between $797.5 \mathrm{~m}$ (stage elevation of $\sim 2,020$ $\mathrm{m}^{3} / \mathrm{s}$ ) and the Colorado River at base flow. Most of the erosion evident below an elevation of 797.5 $\mathrm{m}$ is attributed to knickpoint retreat resulting from an unusual weather system that produced widespread rain and tributary debris flows to the Colorado River in the vicinity of the Palisades gully network on September 7, 2002 (Hazel and others, 2008a). Above this elevation, no significant change was detected over the same time period.

Long-term thalweg evolution of the Palisades North gully is shown in figure 9. This gully has remained relatively unchanged during 12 years of monitoring. Check dam installation and maintenance may explain the lack of detectable change at this gully, but the lack of detectable change also may be attributable to the variable survey coverage and different point densities between surveys. 

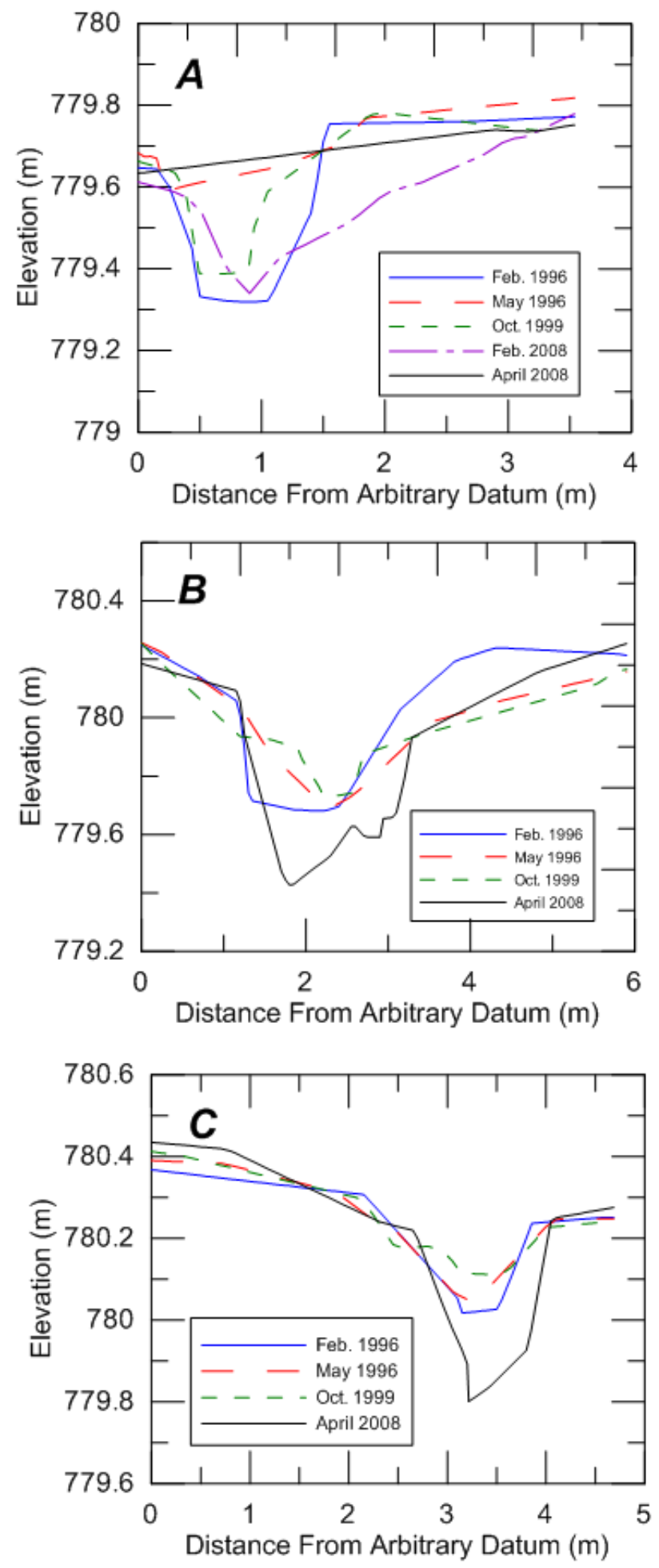

Figure 10. Cross sections at the Furnace Flats gully, Grand Canyon National Park, Arizona. ( $A$ ) Cross section 10; $(B)$ cross section 11; and $(C)$ cross section 12. All cross section locations are shown in figure 5 , and are viewed in a down-gully direction. 


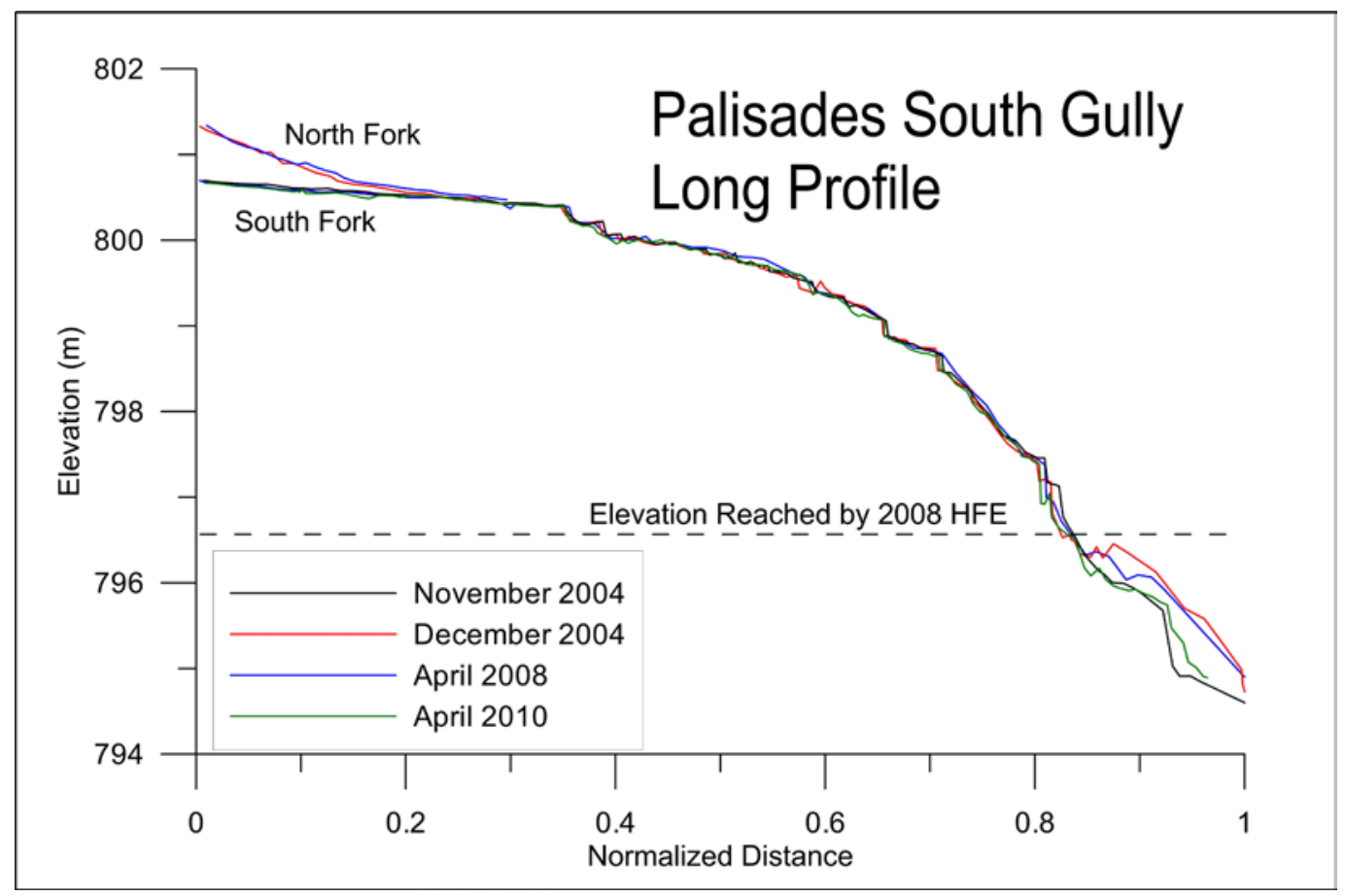

Figure 11. Normalized long profile of the Palisades South gully, Grand Canyon National Park, Arizona, 2004-2010. Gully long profile endpoints are shown in figure 3. Profile length between endpoints is approximately 308 meters.

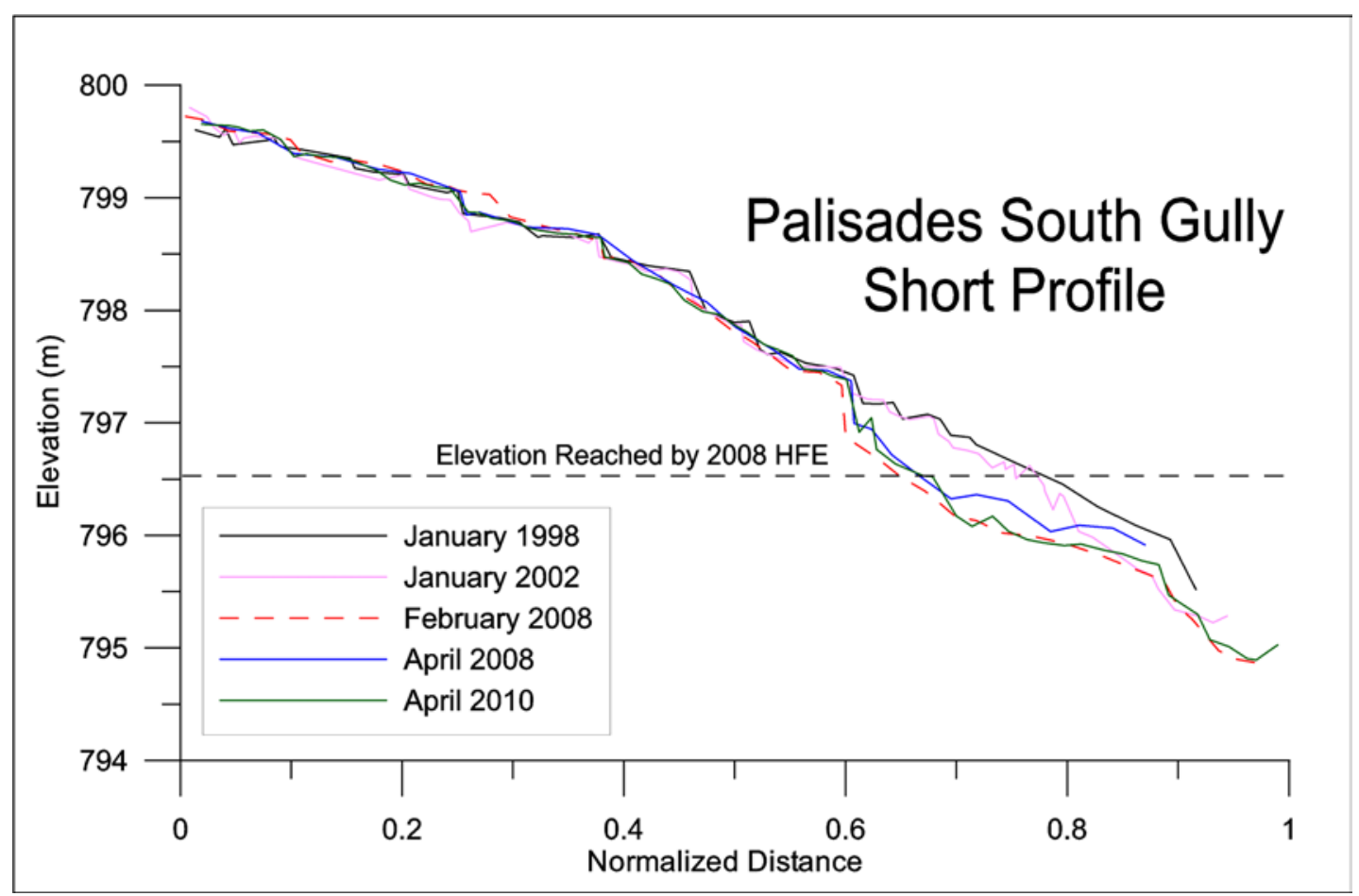

Figure 12. Normalized short profile of the Palisades South gully, Grand Canyon National Park, Arizona, 1998-2010. Gully short profile endpoints are shown in figure 3. Profile length between endpoints is approximately 135 meters. 
The evolution of the Furnace Flats gully thalweg (fig. 13) is markedly different than that of the Palisades North gully. The Furnace Flats gully thalweg aggraded between February 1996 and October 1998. Aggradation may be attributed to sediment deposition in the gully mouth during the 1996 HFE, aeolian deposition, or gully-wall collapse. Some, but not all, of this aggradation was eroded between October 1998 and October 1999. The long-term evolution of the Furnace Flats gully is characterized by substantial erosion, as evidenced by more than $0.2 \mathrm{~m}$ of incision across the entire thalweg profile between October 1999 and April 2008. Average point spacing for the Furnace Flats thalweg surveys ranged from $1 \mathrm{pt} / 1.3 \mathrm{~m}$ to $1 \mathrm{pt} / 1.8 \mathrm{~m}$ between the different surveys. The Furnace Flats gully has received no erosion mitigation actions, is rarely visited by recreationists, and is perhaps a better reflection of natural gully evolution in the Grand Canyon.

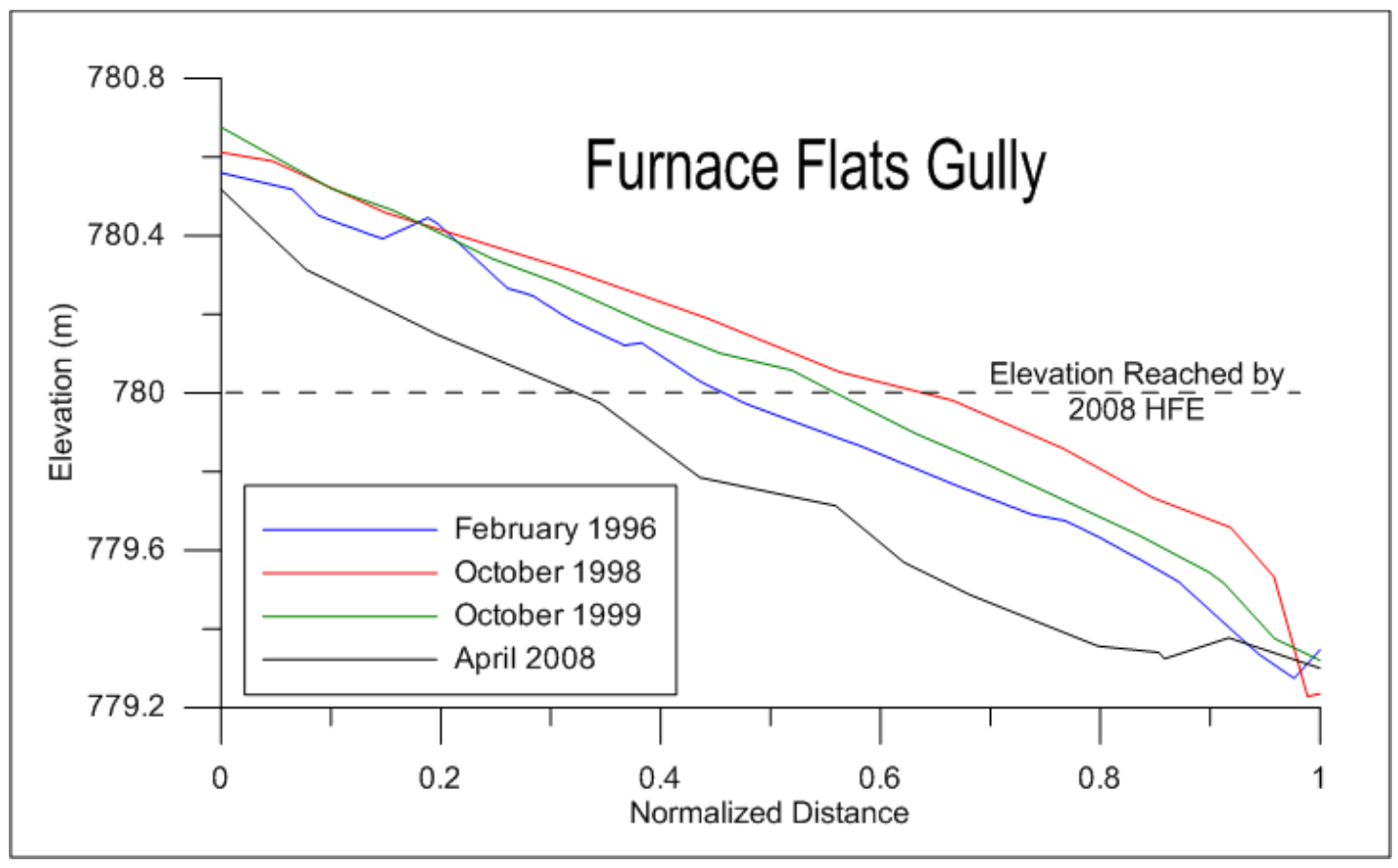

Figure 13. Normalized profile of the Furnace Flats gully, Grand Canyon National Park, Arizona, 1996-2008. Gully profile endpoints are shown in figure 5. Profile length between endpoints is approximately 23 meters.

\section{Channel Widening}

Channel widening at Palisades was examined by comparing the 2008 surveys to the surveys collected by Hazel and others (2008a) in 2004 at cross-section locations established by the National Park Service in 1998. Repeat surveys of the cross sections provide another glimpse into long-term gully evolution. Nearly all cross sections at the Palisades gully network show varying degrees of gully-wall erosion or wall slumping since 1998. Cross section 4 (fig. 14A) shows gully widening of more than $0.5 \mathrm{~m}$ between January 1998 and April 2008. Cross section 5 (fig. 14B) shows evidence of gully-wall slumping and smoothing of the gully floor during the same 10-year period. Cross sections 6, 7, and 8 (figs. 14C, 14D, and 14E) also indicate evidence of gully-wall slumping. The one cross section established by the National Park Service at the Palisades North gully indicates substantial wall slumping and sediment redistribution within the gully (fig. 14F). At all Palisades 

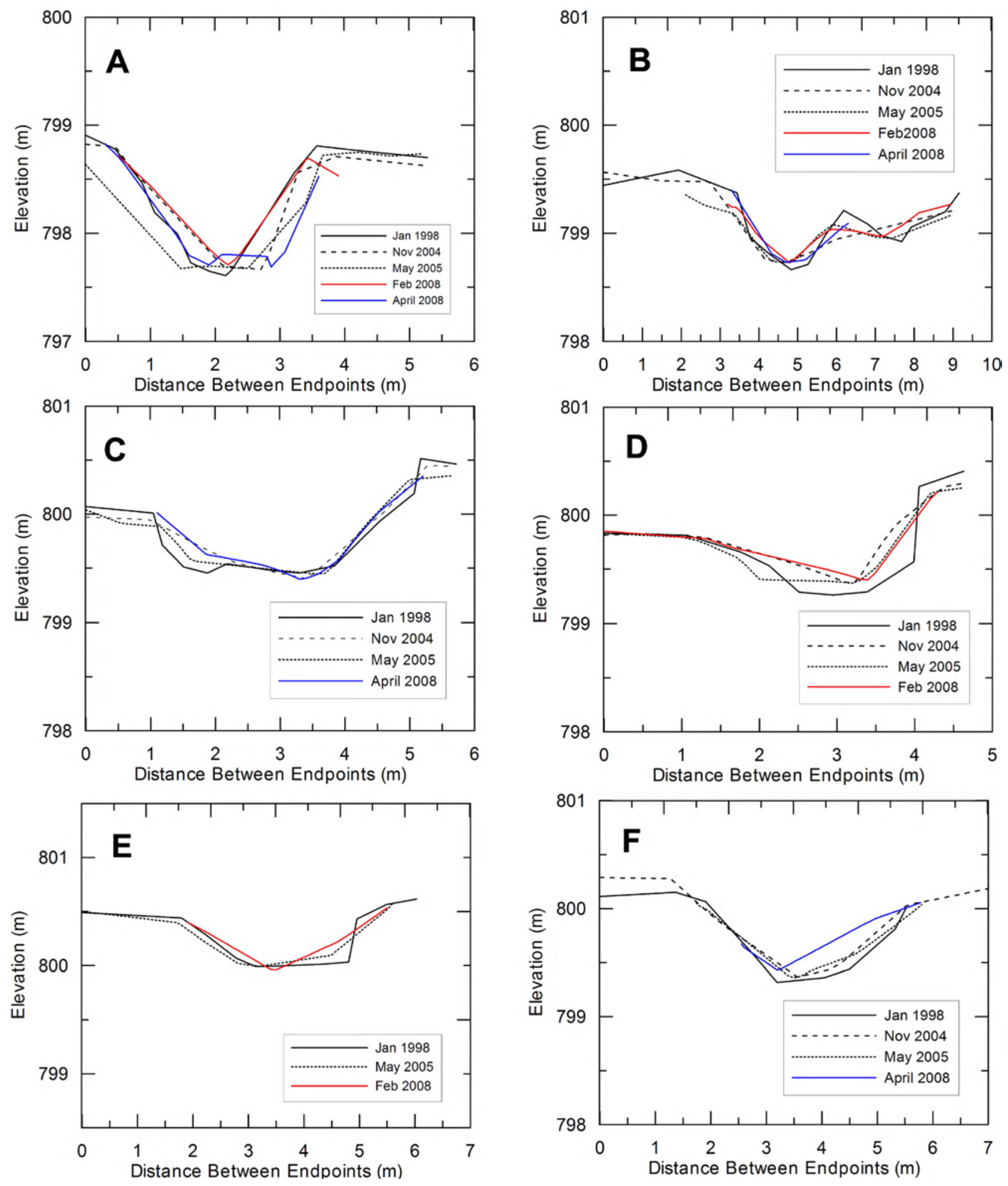

Figure 14. Cross sections at the Palisades gully network established by the National Park Service, Grand Canyon National Park, Arizona, January 1998. (A) Cross section 4; (B) cross section 5; (C) cross section 6; (D) cross section 7; (E) cross section 8; and (F) cross section 9. All cross section locations are shown in figure 3 and are viewed in a down-gully direction. Modified from Hazel and others (2008a). 
cross sections, gully thalweg elevations changed very little over the decade after establishment of the cross sections. Thus, either the material eroded from gully walls was transported through the gully network during runoff events without affecting gully thalweg elevation, or thalweg incision was offset by sediment derived from slumping gully walls.

In contrast to the changes at the Palisades gullies, the cross sections at the Furnace Flats gully show progressive incision and gully widening between 1996 and 2008 (fig. 10). These cross sections were established by Hazel and others (2000). Cross section 10, located on a flooddeposited sandbar, has been discussed above. Cross section 11 shows the formation of a tributary to the main gully between October 1999 and April 2008 (fig. 10B). More than $0.5 \mathrm{~m}$ of gully widening is evident at cross section 12 (fig. 10C). Between 1996 and 2008, there was as much as $0.3 \mathrm{~m}$ of thalweg incision above the elevation inundated during HFEs (figs. 10B and 10C).

\section{Discussion}

\section{High-Flow Experiment}

Sediment was deposited into the mouth of the Palisades South gully by the 2008 HFE. The net deposition in 2008 was $1 \mathrm{~m}^{3}$, an amount considerably less than the $10 \mathrm{~m}^{3}$ deposited by the 2004 HFE. The difference in sediment deposition may be explained by the available accommodation space within the gully mouth at the time of the 2008 HFE. Hazel and others (2008a) showed that the large difference in sediment deposition between the 1996 and the $2004 \mathrm{HFE}$ was the result of $0.5 \mathrm{~m}$ of gully thalweg incision in the mouth area between 1999 and the $2004 \mathrm{HFE}$, evacuation of $63 \mathrm{~m}^{3}$ of material from the mouth area between the two floods, and complete removal of four check dams that were present in the 1990s, thus increasing accommodation space available for deposition during the 2004 HFE. In our present study, only about one-half of the $10 \mathrm{~m}^{3}$ of fine sediment deposited by the 2004 HFE had eroded prior to the 2008 HFE. Thus, remnant sediment from the 2004 HFE reduced the amount of space available for 2008 HFE derived sediment, resulting in a reduced volume of deposition. However, we cannot rule out differences in sediment-supply and sand concentrations between the two HFEs as other causal factors contributing to the reduced depositional volume in 2008.

The 2008 HFE also deposited fine sediment in the mouth of the Furnace Flats gully. The 2008 HFE deposits buried a portion of the old gully thalweg under approximately $0.3 \mathrm{~m}$ of sediment (fig. 10A). Although the exact amount of sediment deposition cannot be calculated, the post-flood survey confirms that sediment was deposited in the gully mouth during the $2008 \mathrm{HFE}$. In contrast, the Palisades North gully remained relatively unaffected by all three HFEs, a response attributed to an inundation depth of less than $0.4 \mathrm{~m}$ during the HFEs (Hazel and others, 2008a).

\section{Long-Term Changes}

There is a distinct difference in the long-term changes observed at the Palisades gully network and the Furnace Flats gully, despite both being located in the Furnace Flats geomorphic reach of the eastern Grand Canyon. These differences may be explained by differing catchment types and areas, dissimilar sedimentology of the eroding substrate, distinctive vegetative cover, and altered micro-climate variables. The installation and maintenance of ECS also may play a role in explaining long-term differences. 


\section{Palisades Gully Network}

Long-term topographic change at the Palisades South gully is markedly different above and below an elevation of $797.5 \mathrm{~m}$ (about $2,020 \mathrm{~m}^{3} / \mathrm{s}$ stage). Between this elevation and the Colorado River at base flow (about $794.6 \mathrm{~m}$ ), significant erosion is evident (fig. 12). Prior to the $2008 \mathrm{HFE}$, most of the thalweg profile of the lower reaches of the Palisades South gully was approximately 0.5 $\mathrm{m}$ lower than the thalweg elevation measured in January 1998. Although sediment was deposited in the elevations reached by experimental floods, by April 2010, the thalweg profile still remained about $0.3-0.4 \mathrm{~m}$ below the January 1998 profile. Much of this erosion has been explained by a large precipitation event that occurred on September 7, 2002 (see Hazel and others, 2008a).

Gully widening, which mostly erodes sediment not deposited by recent HFEs, is among the most important threats to the preservation of cultural deposits and their associated artifacts. The lower reaches of the Palisades South gully also show evidence of erosion by means of gully widening processes (fig. 15), including gully-wall slumping and gully-wall retreat. Pederson and others (2006) suggest that damaged ECS, especially failed rock check dams, tend to further exacerbate erosion. Hazel and others (2008a) report that several check dams present in the lower reaches of the Palisades South gully in the 1990s had washed out prior to the 2004 HFE. To date, they have not been rebuilt and may be a contributing factor in explaining erosion at the lower elevations of the Palisades South gully. Our surveys also show that HFEs can widen gullies within

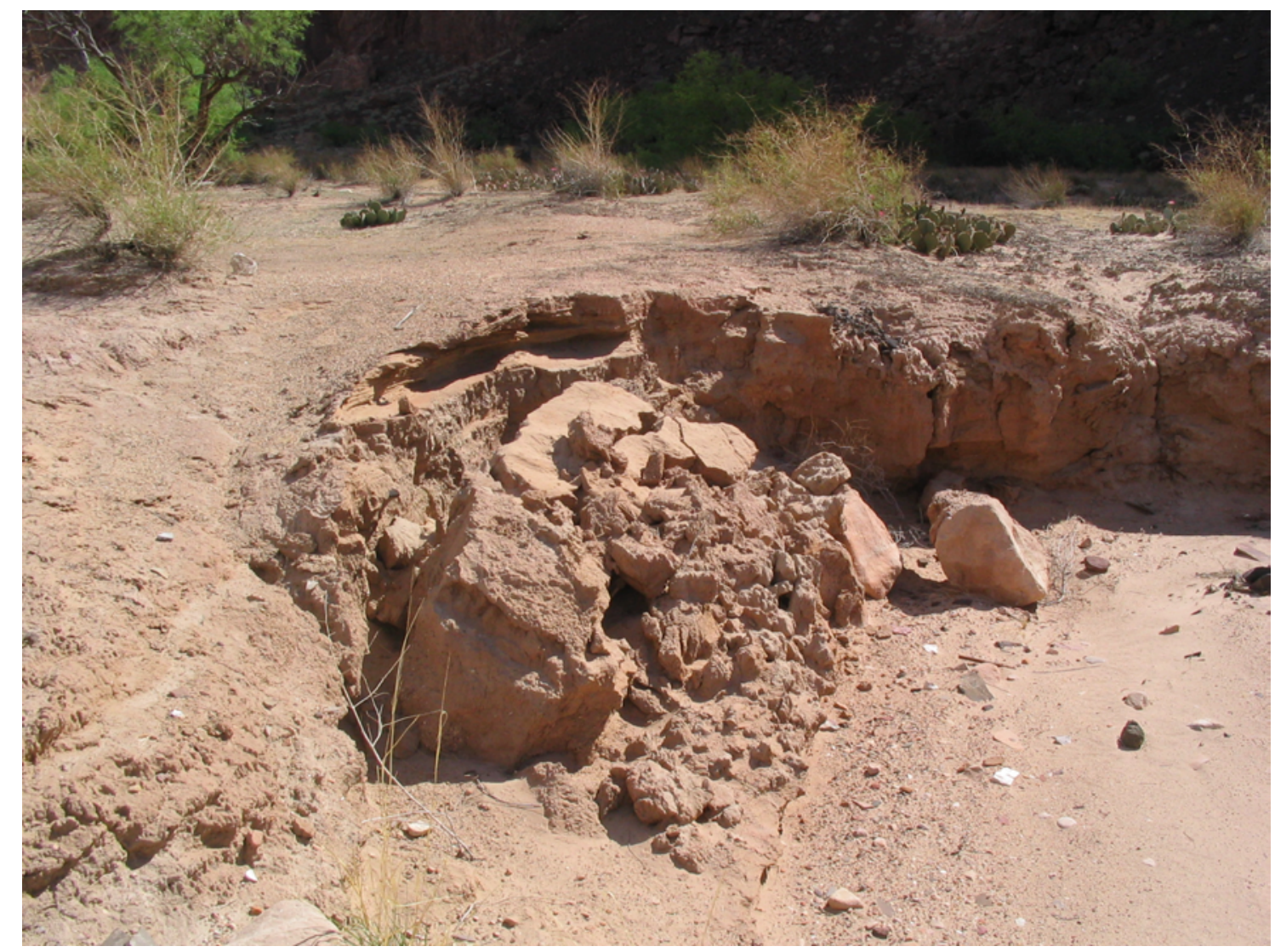

Figure 15. Photograph showing an example of gully-wall slumping at the Palisades South gully, Grand Canyon National Park, Arizona. Photograph taken by J. Hazel, Northern Arizona University, April 19, 2007. 
the inundation zone. Although we may not be able to determine all causal factors, we do know that the lowest elevations of the Palisades South gully have shown progressive erosion by means of thalweg incision and gully widening processes over the monitoring record.

The uppermost elevations of the Palisades South gully show relatively little change between 2004 and 2010 (fig. 11). Although slight thalweg aggradation is evident between 2004 and 2008, explaining the aggradation in the upper reaches is complicated by point spacing issues and installation and maintenance of ECS in March 2005 (Dierker and Leap, 2006). Evidence of gullywall slumping in the higher elevations of the Palisades South gully (fig. 15) may explain the slight increase in gully thalweg elevation between 2004 and 2008. Although gully widening is a natural process in the Grand Canyon, some have suggested that it might be exacerbated by anthropogenic influences during monitoring efforts (see Collins and others, 2008), installation and maintenance (or lack thereof) of ECS (Pederson and others, 2006), and excavation of at-risk cultural sites (Collins and others, 2012). Although identifying the causes of gully widening, anthropogenic or not, is beyond the scope of this study, we conclude that the gully thalweg did slightly aggrade at the higher elevations of the Palisades South gully between 2004 and 2008. We attribute this aggradation to both widening of the gully (and deposition of this gully side-wall material in the thalweg), and infilling behind recently installed or maintained ECS. By April 2010, all evidence of thalweg aggradation had disappeared, and the thalweg profile very closely resembled the profile observed in November and December 2004. Gully-wall slumping and anthropogenic influences likely mitigated any thalweg incision that might have occurred between 2004 and 2010 in the uppermost reaches of the Palisades South gully.

The Palisades North gully remained relatively stable between January 1998 and April 2008. We attribute the differences in the gully thalweg profiles shown in figure 9 to the variance caused by the different spacing of the ground points used to generate the profile, and the fact that not all surveyors collected thalweg profile data at exactly the same locations along the thalweg. Both brush and rock check dams were constructed at the Palisades North gully in 1995 and have been maintained or rebuilt in February 1997, February 1998, April 2000, October 2000, March 2003, March 2004, and March 2005 (Dierker and Leap, 2006), and perhaps at other times not yet reported. We believe that installation and maintenance of ECS, including check dams and wall armoring, could be partially responsible for stabilizing this gully. Slumping of the gully wall (shown in fig. 14F) and redistribution of this material to the thalweg also may play a role in the stability of the Palisades North gully profile.

\section{Furnace Flats Gully}

The Furnace Flats gully is an actively eroding gully, showing evidence of thalweg incision, gully widening, and formation of new tributaries to the main gully. The Furnace Flats gully is not located at a known archaeological site, so no cultural artifacts or structures have been lost as a result of gully erosion; however, this gully is similar in size and extent to other gullies located nearby where archaeological artifacts have been observed (see http://www.nps.gov/grca/historyculture/archeology-excavation.htm). 
No excavations, monitoring, or check dam installations have occurred at the Furnace Flats site, so widening at this gully can be interpreted as a natural process that may or may not have been exacerbated by recent survey activities. Explaining why the Furnace Flats gully is actively eroding while the Palisades North gully (a gully similar in size) is stable is complicated by differences in catchment area, substrate, and slope. Geomorphic and sedimentological studies of the catchment area and the eroding substrate would help to separate the influence of ECS from other factors affecting erosion rates and characteristics at the two sites. More intense data collection efforts also would aid in understanding erosion characteristics as this site.

\section{Base-Level Hypothesis}

Some scientists have suggested that the introduction of experimental floods in the Grand Canyon may be able to offset and potentially even reverse some gully erosion by back-filling gully mouths, thereby temporarily raising the "effective" base level of gullies and replenishing the sand sources that support additional back-filling of gullies by aeolian processes (Hereford and others, 1993; Yeatts, 1996; Thompson and Potochnik, 2000; see also U.S. Department of Interior, 2008). Hereford and others (1993) suggested that the effective base-level of gullies has decreased by 3 or $4 \mathrm{~m}$ in the post-dam era. Although our study shows that sediment has been deposited in gully mouths during HFEs, increases in the gully bottom elevations generally are less than $1 \mathrm{~m}$.

Our study also shows that HFE deposits are relatively short-lived, limiting their ability to impact long-term gully stability. HFE-derived sediment is fine-grained, unconsolidated, and highly erodible. In the gullies investigated in this report, most HFE derived sediment was evacuated from the mouth area within a couple of years.

Because a multitude of factors affect gully erosion in the Grand Canyon, we believe that the gullies reported on in this investigation may not be representative of all gullies in the Grand Canyon. Although HFEs do appear to temporarily increase the lower thalweg elevation of certain gullies in the Grand Canyon, there is no evidence from the present study to indicate that these short-term changes in gully thalweg elevation influence long-term erosion rates.

\section{Changing Methodologies}

Monitoring gully erosion at our study sites is complicated by differences in survey procedures. All surveys analyzed in this study were collected using electronic total stations. However, because the gully survey project was one piece of a larger survey effort where time and resources were limited, some gully surveys focused on mapping the gully thalweg, while others concentrated on measuring gully cross sections. Certain surveys focused data collection in gully mouths; others surveyed the entire gully. Inter-gully areas have received attention in just a few studies (for example, Collins and others, 2009, 2012). The differing extents and densities of surveys complicate comparison. While methods such as normalizing thalweg profiles and interpolating cross sections from TIN surfaces allow us to track gully evolution, the lack of a consistently applied methodology has introduced unnecessary uncertainty. Much of this uncertainty could be eliminated by establishing and maintaining a standardized and detailed survey procedure. 
A systematic, canyon-wide approach is required to comprehensively monitor gully erosion in the Grand Canyon. Methods described in this report were sufficient to track gully widening and deposition in selected gullies over time; however, in order to more completely understand gully erosion, in the Grand Canyon, a more comprehensive approach is needed. A comprehensive approach would evaluate and categorize all gullies in the Colorado River ecosystem using a suite of relevant attributes (for example, geological setting, size of catchment, gradient, substrate characteristics) and then select a stratified random sample of gully systems to monitor intensively over a period of years. Monitoring the topography of the selected gullies could be accomplished with total stations using a standardized protocol, or using alternate survey methodologies. Groundbased lidar (light detection and ranging) is a promising technology that can provide high-density survey data and is especially useful and cost-effective for measuring detailed changes in topography of inter-gully terrain. Airborne lidar offers a practical, albeit expensive, technique for quantifying gully erosion for the hundreds of gullies that are potentially unearthing archaeological sites in the Grand Canyon. Other remote sensing techniques, such as analysis of aerial photography, offer another avenue for documenting the evolution of many gullies over long timescales, although this method precludes precise quantification of change (Collins and others, 2014). Whatever method is selected, it is important that future monitoring and mapping efforts be carried out with consistent, replicable protocols to ensure that data can be systematically and rigorously collected and compared over time.

\section{Conclusions and Suggestions for Future Work}

This study has found that HFE deposits temporarily increase the thalweg elevation in some gully mouths. These increases typically were less than $0.6 \mathrm{~m}$ at the sites we studied. Additionally, this study reconfirmed previous observations indicating that increases in gully mouth elevation due to deposition of unconsolidated, highly erodible sediment are short-lived in the Grand Canyon. Thus, unless HFEs are of greater magnitude in the future, and occur with greater frequency than they have in the recent past, deposition of sediment in gully mouths by future HFEs is not likely to change gully erosion rates significantly, and gully erosion will likely continue until gullies have equilibrated with the post-dam base-level flows.

Our ability to understand gully erosion and the role of dam operations in contributing to the erosion of archaeological sites in the Grand Canyon has been hampered by the lack of a welldesigned, consistent approach to monitoring changes in physical context. To help understand gully evolution and rates of gully erosion or aggradation in the Grand Canyon, it is imperative that future mapping encompass the entire length of gullies and their tributaries. Standardized data-collection methodologies, including increased cross-section analysis and use of an appropriately designed sample of gullies that reflect the range of geomorphic, topographic, and substrate diversity, along with maintained and unmaintained ECS plus a control group of unmodified gullies, would allow for a rigorous evaluation of the effects of erosion control treatments and gully-wall slumping on gully erosion/aggradation rates. Mapping of intervening terrain, sedimentological studies of catchment areas and the eroding substrate, and precise measurement of local weather events and the resulting runoff also can aid in increasing our understandings of gully erosion in the Grand Canyon. Until a well-coordinated monitoring program can be implemented and carried out consistently over an extended time period, it will be difficult to determine the primary factors affecting gully erosion/aggradation rates and thus, determine the best strategies for protecting cultural resources. 


\section{References Cited}

Collins, B.D., Brown, K.B., and Fairley, H., 2008, Evaluation of Terrestrial LIDAR for monitoring geomorphic change at archaeological sites in Grand Canyon National Park, Arizona: U.S. Geological Survey Open-File Report 2008-1384, 60 p., http://pubs.usgs.gov/of/2008/1384/.

Collins, B.D., Corbett, S.C., Fairley, H.C., Minasian, D., Kayen, R., Dealy, T.P., and Bedford, D.R., 2012, Topographic change detection at select archeological sites in Grand Canyon National Park, Arizona, 2007-2010: U.S. Geological Survey Scientific Investigations Report 2012-5133, $77 \mathrm{p}$.

Collins, B.D., Minasian, D., and Kayen, R., 2009, Topographic change detection at select archaeological sites in Grand Canyon National Park, Arizona, 2006-2007: U.S. Geological Survey Scientific Investigations Report 2009-5116, 97 p., http://pubs.usgs.gov/sir/2009/5116/.

Collins, B.D., Corbett, S.C., Sankey, J.B., and Fairley, H.C., 2014, High-resolution topography and geomorphology of select archeological sites in Glen Canyon National Recreation Area, Arizona: U.S. Geological Survey Scientific Investigations Report 2014-5126, 31 p., http://dx.doi.org/10.3133/sir20145126.

Dierker, J., and Leap, L.M., 2006, Fiscal year 2005 archaeological site monitoring and management activities along the Colorado River in Grand Canyon National Park: Grand Canyon National Park and Northern Arizona University, Draft report submitted to the Bureau of Reclamation, Report no. 91, 151 p.

Draut, A., 2012, Effects of river regulation on aeolian landscapes, Colorado River, southwestern USA: Journal of Geophysical Research - Earth Surface, v. 117, F2, doi:10.1029/2011JF002329.

Draut, A.E., Andrews, T., Fairley, H.C., and Brown, C.R., 2009a, 2007 weather and aeolian sandtransport data from the Colorado River corridor, Grand Canyon, Arizona: U.S. Geological Survey Open-File Report 2009-1098, 110 p., http://pubs.usgs.gov/of/2009/1098/.

Draut, A.E., and Rubin, D.M., 2008, The role of eolian sediment in the preservation of archeologic sites along the Colorado River corridor in Grand Canyon National Park, Arizona: U.S. Geological Survey Professional Paper 1756, 71 p., http://pubs.usgs.gov/pp/1756].

Draut, A.E, Rubin, D.M., Dierker, J.L., Fairley, H.C., Griffiths, R.E., Hazel, J.E., Jr., Hunter, R.E., Kohl, K., Leap, L.M., Nials, F.L., Topping, D.J., and Yeatts, M., 2005, Sediment and stratigraphy of the Palisades, Lower Comanche, and Arroyo Grande Areas of the Colorado River corridor, Grand Canyon, Arizona: U.S. Geological Survey Scientific Investigations Report 20055072, 74 p., http://pubs.usgs.gov/sir/2005/5072/.

Draut, A.E., Sondossi, H.A., Hazel, J.E., Jr., Andrews, T., Fairley, H.C., Brown, C.R., and Vanaman, K.M., 2009b, 2008 weather and aeolian sand-transport data from the Colorado River corridor, Grand Canyon, Arizona: U.S. Geological Survey Open-File Report 2009-1190, 98 p., http://pubs.usgs.gov/of/2009/1190/.

Draut, A.E., Sondossi, H.A., Dealy, T.P., Hazel, J.E., Fairley, H.C., and Brown, C.R., 2010, 2009 weather and aeolian transport data from the Colorado River corridor, Grand Canyon, Arizona: U.S. Geological Survey Open-File Report 2010-1166, 98 p., http://pubs.usgs.gov/of/2010/1166/. Fairley, H.C., 2003, Changing river-Time, culture, and the transformation of landscape in Grand Canyon-A regional research design for the study of cultural resources along the Colorado River in lower Glen Canyon and Grand Canyon, National Park, Arizona: Statistical Research, Inc., Technical Series 79, http://www.gcmrc.gov/library/reports/cultural/Archaeology/Fairley2003.pdf.

Fairley, H.C., 2005, Cultural resources in the Colorado River corridor, in Gloss, S.P., Lovich, J.E., and Melis, T.S., eds., The state of the Colorado River ecosystem in Grand Canyon: U.S. Geological Survey Circular 1282, p. 177-192. 
Fairley, H.C., Bungart, P.W., Coder, C.M., Huffman, J., Samples, T.L., and Balsom, J.R., 1994, The Grand Canyon river corridor survey project-Archaeological survey along the Colorado River between Glen Canyon Dam and Separation Rapid: Flagstaff, Ariz., Bureau of Reclamation Glen Canyon Environmental Studies Program, cooperative agreement no. 9AA-40-07920.

Fairley, H.C., Draut, A., Collins, B., Corbett, S., Bedford, D., Davis, P., and Sankey, J., 2012, Project J-Monitoring cultural resources and at small scale and defining the large-scale geomorphic context of the processes affecting cultural resources, in Department of Interior, Bureau of Reclamation, Upper Colorado River Regional Office, and U.S. Geological Survey, Grand Canyon Monitoring and Research Center: Glen Canyon Dam Adaptive Management Program Biennial Budget and Work Plan-Fiscal Years 2013-14., p. 220-268, http://www.usbr.gov/uc/rm/amp/amwg/mtgs/12aug29/Attach_08b.pdf.

Hazel, J.E., Jr., Kaplinski, M., Manone, M., and Parnell, R., 2000, Monitoring arroyo erosion of pre-dam river terraces in the Colorado River ecosystem, 1996-1999, Grand Canyon National Park, AZ: Flagstaff, Ariz., Report on file at the Grand Canyon Monitoring and Research Center, $29 \mathrm{p}$.

Hazel, J.E., Jr., Kaplinski, M., Parnell, R.A., and Fairley, H.C., 2008a, Aggradation and degradation of the Palisades gully network, 1996 to 2005, with emphasis on the November 2004 high-flow experiment, Grand Canyon National Park, Arizona: U.S. Geological Survey Open-File Report 2008-1264, 14 p.

Hazel, J.E., Jr., Kaplinski, M., Parnell, R., Kohl, K., and Schmidt, J.C., 2008b, Monitoring finegrained sediment in the Colorado River Ecosystem, Arizona-Control network and conventional survey techniques: U.S. Geological Survey Open-File Report 2008-1276, 15 p.

Hazel, J.E., Jr., Kaplinski, M., Parnell, R., Kohl, K., and Topping, D.J., 2006, Stage-discharge relations for the Colorado River in Glen, Marble, and Grand Canyons, Arizona: U.S. Geological Survey Open-File Report 2006-1243, 7 p.

Hereford, R., 1996, Map showing surficial geology and geomorphology of the Palisades Creek area, Grand Canyon National Park, Arizona: U.S. Geological Survey Miscellaneous Investigations Series Map I-2449, scale 1:2000 (with discussion). 12 p. 1 plate.

Hereford, R., Fairley, H.C., Thompson, K.S., and Balsom, J.R., 1993, Surficial geology, geomorphology and erosion of archeologic sites along the Colorado River, eastern Grand Canyon, Grand Canyon National Park, Arizona: U.S. Geological Survey Open-File Report 93517,45 p., 4 pl.

Hereford, R., Thompson, K.S., Burke, K.J., and Fairley, H.C., 1996, Tributary debris fans and Late Holocene alluvial chronology of the Colorado River, eastern Grand Canyon, AZ: General Services Administration Bulletin, v. 108, no. 1, p. 3-19.

Howard, A., and Dolan, R., 1981, Geomorphology of the Colorado River in Grand Canyon: Journal of Geology, v. 89, no. 3, p. 269-297.

Huntoon, P.W., Billingsley, G.H., Breed, W.J., Sears, J.W., Ford, T.D., Clark, M.D., Babcock, R.S., and Brown, E.H., 1986, Geological map of the eastern part of Grand Canyon National Park, Arizona: Grand Canyon, Ariz., Grand Canyon Natural History Association, scale 1:62,500.

Leap, L.M., and Coder, C.M., 1995, Erosion control project at Palisades delta along the Colorado River corridor, Grand Canyon National Park: Salt Lake City, Utah, River Corridor Monitoring Project, Report no. 73 prepared for the Bureau of Reclamation.

Leap, L.M., Kunde, J.L., Hubbard, D.C., Andrews, N., Downum, C.E., Miler, A., and Balsom, J.R., 2000, Grand Canyon Monitoring Project 1992-1999_-Synthesis and Annual Monitoring Report FY99: Salt Lake City, Utah, Grand Canyon National Park River Corridor Monitoring Project Report No. 66, submitted to Bureau of Reclamation. 
McKee, E.D., 1938, Original structures in Colorado River flood deposits: Journal of Sedimentary Petrology, v. 8, no. 3, p. 77-83.

Melis, T.S., ed., 2011, Effects of three high-flow experiments on the Colorado River ecosystem downstream from Glen Canyon Dam, Arizona: U.S. Geological Survey Circular 1366, 147 p.

Melis, T.S., Grams, P.E., Kennedy, T.A., Ralston, B.E., Robinson, C.T., Schmidt, J.C., Schmit, L.M., Valdez, R.A., and Wright, S.A., 2011, Three experimental high-flow releases from Glen Canyon Dam, Arizona_Effects on the downstream Colorado River ecosystem: U.S. Geological Survey Fact Sheet 2011-3012, 4 p.

Pederson, J.L., Petersen, P.A., MacFarlane, W.W., Gonzales, M.F., and Kohl, K., 2003, Mitigation, monitoring, and geomorphology related to gully erosion of cultural sites in Grand Canyon: Flagstaff, Ariz., Grand Canyon Monitoring and Research Center, Final report in fulfillment of Cooperative Agreement CA-01-WRAG-0074, 250 p., http://www.gcmrc.gov/library/reports/cultural/Archaeology/Pederson2003.pdf.

Pederson, J.L., Peterson, P.A., and Dierker, J.L., 2006, Gullying and erosion control at archaeological sites in Grand Canyon: Earth Surface Processes and Landforms, v. 31, p. 507-525.

Sankey, J.B., and Draut, A.E., 2014, Gully annealing by aeolian sediment-Field and remotesensing investigation of aeolian-hillslope-fluvial interactions, Colorado River corridor, Arizona, USA: Geomorphology, v. 220, p. 68-80, ISSN 0169-555X, http://dx.doi.org/10.1016/j.geomorph.2014.05.028.

Schmidt, J.C., and Graf, J.B., 1990, Aggradation and degradation of alluvial sand deposits, 1965 to 1986, Colorado River, Grand Canyon National Park, Arizona: U.S. Geological Survey Professional Paper 1493, 74 p.

Thompson, K.S., and Potochnik, A.R., 2000, Development of a geomorphic model to predict erosion of pre-dam Colorado river terraces containing archaeological resources: Flagstaff, Ariz., SWCA, Inc., SWCA Cultural Resources Report No. 99-257, prepared for Grand Canyon Monitoring and Research Center.

Topping, D.J., Rubin, D.M., and Vierra, L.E., Jr., 2000, Colorado River sediment transport pt.1Natural sediment supply limitations and the influence of the Glen Canyon Dam: Water Resources Research, v. 36, no. 2, p. 515-542.

Topping, D.J., Rubin, D.M., Schmidt, J.C., Hazel, J.E., Jr., Melis, T.S., Wright, S.A., Kaplinski, M., Draut, A.E., and Breedlove, M.J., 2006, Comparison of sediment-transport and bar-response results from the 1996 and 2004 controlled-flood experiments on the Colorado River in Grand Canyon: CD-ROM Proceedings of the Eighth Federal Inter-Agency Sedimentation Conference, Reno, Nev., April 26, 2006, ISBN 0-9779007-1-1.

Topping, D.J., Schmidt, J.C., and Vierra, L.E., Jr., 2003, Computation and analysis of the instantaneous-discharge record for the Colorado River at Lees Ferry, Arizona-May 8, 1921, through September 30, 2000: U.S. Geological Survey Professional Paper 1677, 118 p.

U.S. Department of the Interior, 1995, Operation of Glen Canyon Dam final environmental impact statement, Colorado River Storage Project, Coconino County, Arizona: Salt Lake City, Utah, Bureau of Reclamation, Upper Colorado Regional Office, Utah, 337 p.

U.S. Department of the Interior, 1996, Record of Decision, Operation of Glen Canyon Dam Final Environmental Impact Statement, Colorado River Storage Project, Coconino County, Arizona: Salt Lake City, Utah, Bureau of Reclamation, 337 p.

U.S. Department of the Interior, 2008, Final environmental assessment for experimental releases from Glen Canyon Dam, Arizona, 2008 through 2012: Salt Lake City, Utah, Bureau of Reclamation, 68 p., accessed October 19, 2010, at http://www.usbr.gov/uc/envdocs/ea/gc/2008hfe/index.html. 
Valentin, C., Poesen, J., and Li, Y., 2005, Gully erosion-Impacts, factors and control: Catena, v. 63, p. 132-153.

Webb, R.H., Schmidt, J.C., Marzolf, G.R., and Valdez, R.A., eds., 1999, The controlled flood in Grand Canyon-Scientific experiment and management demonstration: Washington, D.C., American Geophysical Union, Geophysical Monograph Series, v. 110, 367 p.

Wiele, S.M., and Torizzo, M., 2005, Modeling of sand deposition in archeologically significant reaches of the Colorado River in Grand Canyon, USA, in Bates, P., Lane, S., and Ferguson, R., eds., Computational Fluid Dynamics - Applications in Environmental Hydraulics: West Sussex, England, John Wiley and Sons, p. 357-394.

Wright, S.A., Melis, T.S., Topping, D.J., and Rubin, D.M., 2005, Influence of Glen Canyon Dam operations on downstream sand resources of the Colorado River in Grand Canyon, in Gloss, S.P., Lovich, J.E., and Melis, T.S., eds., The state of the Colorado River ecosystem in Grand Canyon: U.S. Geological Survey Circular 1282, 1,731 p.

Yeatts, M., 1996, High elevation sand deposition and retention from the 1996 spike flow-An assessment for cultural resources stabilization: Report on file at the Grand Canyon Monitoring and Research Center, Flagstaff, Ariz., 32 p.

Yeatts, M., 1998, High elevation sand retention following the 1996 spike: Report on file at the Grand Canyon Monitoring and Research Center, Flagstaff, Ariz., 15 p. 
This page left intentionally blank 
Publishing support provided by the U.S. Geological Survey

Science Publishing Network, Tacoma Publishing Service Center

For more information concerning the research in this report, contact the SBSC staff, Southwest Biological Science Center

U.S. Geological Survey

2255 N. Gemini Drive

Flagstaff, AZ 86001

http://sbsc.wr.usgs.gov/ 


\section{हू}

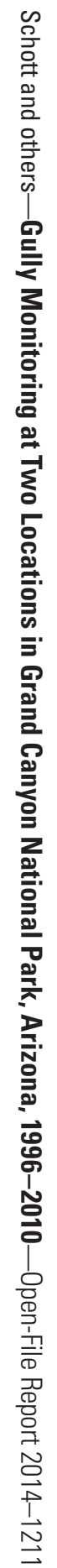

